\title{
The replacement of plagioclase feldspars by albite: observations from hydrothermal experiments
}

\author{
Jörn Hövelmann · Andrew Putnis · Thorsten Geisler • \\ Burkhard C. Schmidt · Ute Golla-Schindler
}

Received: 20 January 2009/Accepted: 3 June 2009/Published online: 24 June 2009

(C) Springer-Verlag 2009

\begin{abstract}
Oligoclase and labradorite crystals have been experimentally replaced by albite in an aqueous sodium silicate solution at $600^{\circ} \mathrm{C}$ and $2 \mathrm{kbars}$. The replacement is pseudomorphic and is characterised by a sharp chemical interface which progresses through the feldspar while preserving the crystallographic orientation. Reaction rims of albite, up to $50 \mu \mathrm{m}$ thick, can be readily achieved within 14 days. Re-equilibration of plagioclase in an ${ }^{18} \mathrm{O}$-enriched sodium- and silica-bearing solution results in oxygen isotope redistribution within the feldspar framework structure. The observed characteristics of the reaction products are similar to naturally albitised plagioclase and are indicative of an interface-coupled dissolution-reprecipitation mechanism. Chemical analyses demonstrate that the albitisation is accompanied by the mobilisation of major, minor and trace elements also including elements such as $\mathrm{Al}$ and $\mathrm{Ti}$ which are commonly regarded as immobile during hydrothermal alteration. The results contribute to developing our understanding of the close association between large-scale
\end{abstract}

Communicated by J. Hoefs.

J. Hövelmann ( $₫)$ · A. Putnis · T. Geisler · U. Golla-Schindler Institut für Mineralogie, Westfälische Wilhelms-Universität Münster, Corrensstrasse 24, 48149 Münster, Germany

e-mail: j.e.hovelmann@fys.uio.no

Present Address:

J. Hövelmann

Physics of Geological Processes (PGP), University of Oslo,

Sem Selands vei 24, 0316 Oslo, Norway

B. C. Schmidt

Experimentelle und Angewandte Mineralogie,

Geowissenschaftliches Zentrum Göttingen,

Georg-August Universität Göttingen, Goldschmidtstr. 1,

37077 Göttingen, Germany albitisation and secondary ore mineralisation which is common in nature.

Keywords Plagioclase albitisation · Fluid-mineral interaction - Interface-coupled dissolution-reprecipitation . Hydrothermal experiments · Element mobility

\section{Introduction}

Mineral replacement reactions in nature are commonly associated with fluid-rock interaction and metasomatism (Putnis 2002). The replacement of alkali and plagioclase feldspars by albite is a prevalent phenomenon in the Earth's upper crust. This process, known as albitisation, takes place in a wide variety of rock types and tectonic settings, e.g. during burial diagenesis of feldspar-bearing sandstones (e.g. Boles 1982; Morad et al. 1990; Baccar et al. 1993; Perez and Boles 2005) or the hydrothermal alteration of granites (e.g. Baker 1985; Lee and Parsons 1997; Petersson and Eliasson 1997; Plümper and Putnis 2009), tonalites (e.g. Mark 1998; Engvik et al. 2008), and gabbros (e.g. Niiranen et al. 2005).

When albitisation occurs on a regional scale it is often closely associated with mineral and ore deposits. For instance, the Baltic Shield comprises numerous Fe-oxide$\mathrm{Cu}-\mathrm{Au}$ and $\mathrm{Cu}-\mathrm{Ni}-\mathrm{Zn}$ deposits which are in many cases located in the vicinity of large albitite bodies (e.g. Bjørlykke et al. 1990; Frietsch et al. 1997; Niiranen et al. 2005; Smith et al. 2007). Other prominent examples occur in Australia where similar spatial relationships are present in the Curnamona Province (South Australia) and in the Mt. Isa District (Queensland) (e.g. Mark 1998; Kent et al. 2000; Oliver et al. 2004; Clark et al. 2005). These spatial relationships suggest that albitising fluids are conducive to remobilising elements and are capable of transporting them 
over long distances through crustal rock units before reprecipitation as ore deposits.

To gain a comprehensive understanding of the albitisation process and associated secondary mineralisation processes it is crucial to identify (a) the mechanism of albitisation, (b) the potential of albitising fluids regarding the remobilisation of certain elements and (c) the possible pathways for fluids.

O'Neil and Taylor (1967) already suggested that the cation and oxygen isotope exchange between alkali feldspars and aqueous chloride solutions takes place by a process of fine scale dissolution and redeposition. This process, termed interface-coupled dissolution-reprecipitation (Putnis and Putnis 2007), was later proposed to be the primary mechanism of mineral replacement reactions in the presence of a fluid phase (Putnis 2002). Recently, several experimental studies confirmed that reactions between minerals and a fluid phase, also including simple cation exchange reactions, commonly involve a pseudomorphic replacement via an interface-coupled dissolution-reprecipitation process (e.g. Hellmann et al. 2003; Labotka et al. 2004; Putnis et al. 2005; Harlov et al. 2005; Geisler et al. 2005; Putnis et al. 2007; Niedermeier et al. 2009).

The process of pseudomorphism is understood to begin with superficial congruent dissolution of the parent phase resulting in a thin fluid film which is supersaturated with respect to a more stable phase. Subsequent epitaxial precipitation of the product phase onto the surface of the parent phase preserves its shape and crystallographic orientation while the reaction proceeds into the parent phase. The driving force for such a coupled process is a solubility difference between the parent and the product phase, with the product phase having the lowest solubility in the fluid. This and possibly a smaller molar volume of the product phase results in the generation of porosity within the product phase. If the connectivity of this porosity is high enough the replacement can continue as the fluid is able to reach the reaction interface. The key features of such replacement process are a sharp chemical interface between the parent and the product phase, the preservation of the external dimensions and crystallographic orientation of the parent phase, and the development of porosity within the product phase (Putnis 2002; Putnis and Putnis 2007). Such characteristics have recently been found in naturally albitised plagioclase by Engvik et al. (2008) who suggest that an interface-coupled dissolution-reprecipitation mechanism is responsible for the coupled exchange of $\mathrm{Ca}^{2+}$ and $\mathrm{Al}^{3+}$ by $\mathrm{Na}^{+}$and $\mathrm{Si}^{4+}$ during plagioclase albitisation. However, experimental evidence that plagioclase albitisation is driven by this process is still lacking. Moody et al. (1985) performed experiments on plagioclase albitisation in an aqueous sodium silicate solution. They reported the formation of Na-rich reaction rims around labradorite crystals, possibly resulting from an interface-coupled dissolution-reprecipitation process. Several other experimental studies investigated the reactions between plagioclase feldspars and aqueous chloride solutions in order to obtain data on plagioclase cation exchange equilibria (Orville 1972; Schliestedt and Matthews 1987; Schliestedt and Johannes 1990). It has also been shown in these studies that the exchange rates in the anorthite-producing direction are much faster compared to the albite-producing direction. Therefore, Schliestedt and Johannes (1990) proposed that the anorthite-producing reaction is driven by dissolution and precipitation, whereas the albite-producing reaction proceeds via a diffusionally controlled process.

The mobility of elements during albitisation has been discussed in a number of studies on natural rocks (e.g. Baker 1985; Munz et al. 1994; Petersson and Eliasson 1997; Mark 1998; Oliver et al. 2004). However, direct implications are sometimes difficult to derive from natural environments due to more complex alteration histories resulting from multi-stage processes and a lack of knowledge regarding the chemical composition of albitising fluids. From this point of view it is useful to deal with an experimental system with known physical conditions and chemical compositions of all reactants.

The aim of the present study is to further develop our understanding of the albitisation process via direct experimental investigations of both the replacement mechanism and the accompanying remobilisation of major, minor and trace elements. For this purpose, hydrothermal experiments were performed using an aqueous sodium silicate solution and two different plagioclase compositions (oligoclase and labradorite) as starting material. We also performed an experiment with an ${ }^{18} \mathrm{O}$-enriched solution to test whether the replacement of plagioclase by albite occurs via an interface-coupled dissolution-reprecipitation process as suggested by Engvik et al. (2008). If such a process is indeed operating, all bonds, including those of the $\mathrm{Si}-\mathrm{O}-\mathrm{Al}$ framework, should be broken during the dissolution process and it is expected that the oxygen atoms exchange along with the cations. The reaction products were characterised by scanning electron microscopy (SEM), electron microprobe (EMP), laser ablation-inductively coupled plasmamass spectrometry (LA-ICP-MS), Raman spectroscopy, and transmission electron microscopy (TEM). Our results confirm previous studies and provide additional indications for an interface-coupled dissolution-reprecipitation mechanism. Furthermore, our data demonstrate effective remobilisation of elements during plagioclase albitisation.

\section{Analytical methods}

The reaction products and the starting material were characterised by BSE imaging and energy dispersive X-ray 
analysis (EDX) using a JEOL 840 SEM. Secondary electron (SE) images of grain surfaces were obtained with a JEOL JSM 6300F field emission SEM.

Quantitative analyses of the major and minor elements $\mathrm{Si}, \mathrm{Ti}, \mathrm{Al}, \mathrm{Fe}, \mathrm{Mn}, \mathrm{Mg}, \mathrm{Ca}, \mathrm{Na}$ and $\mathrm{K}$ were carried out using a JEOL JXA 8900 Superprobe. For single measurements and line scans the acceleration voltage was $15 \mathrm{kV}$ at $15 \mathrm{nA}$ beam current. Elemental distribution maps were obtained using operating conditions of $15 \mathrm{kV}$ and $5 \mathrm{nA}$. Na and $\mathrm{K}$ were measured at the beginning of each sequence due to their tendency to volatilise under the electron beam. The ZAF correction procedure was applied to correct for matrix effects.

Single micro-Raman spectroscopic measurements were performed with a Jobin Yvon HR800 Raman system using a Nd-YAG Laser $(532.18 \mathrm{~nm})$ with $10 \mathrm{~mW}$ power at the sample surface. The scattered light was collected in $180^{\circ}$ back-scattering geometry and dispersed by a grating of 1,800 grooves $/ \mathrm{mm}$ after having passed through a $100 \mu \mathrm{m}$ entrance slit. A $100 \times$ objective with a numerical aperture of 0.9 and a confocal hole of $1,000 \mu \mathrm{m}$ was used. The acquisition time was $60 \mathrm{~s}$. Raman mapping was conducted using a Horinba Jobin Yvon LabRam HR800 UV Raman system with an Ar-ion Laser $(488 \mathrm{~nm})$ with $5 \mathrm{~mW}$ power at the sample surface. The scattered light was dispersed by a grating of 2,400 grooves $/ \mathrm{mm}$ on a Peltier cooled CCD detector (Andor ${ }^{\mathrm{TM}}$ ) with 1,024 $\times 256$ pixels. A $100 \times$ objective $($ N.A. $=0.9)$ and a confocal hole of $150 \mu \mathrm{m}$ was used for each mapping procedure, yielding an axial resolution of $<5 \mu \mathrm{m}$ and a lateral resolution of $<1.5 \mu \mathrm{m}$. The spectral dispersion was approximately $0.4 \mathrm{~cm}^{-1}$ per pixel and the acquisition time was $2 \times 20$ or $2 \times 30 \mathrm{~s}$.

Trace element concentrations were analysed by LAICP-MS using a pulsed UP193HE Excimer Laser (New Wave Research) with $193 \mathrm{~nm}$ wavelength for ablation. Each analysis was carried out with a $25 \mu \mathrm{m}$ spot, applying an energy density of $9 \mathrm{~J} / \mathrm{cm}^{2}$ and a repetition rate of $5 \mathrm{~Hz}$. Measurement time was $20 \mathrm{~s}$ for background and $40 \mathrm{~s}$ during ablation. After ablation a washout time of $150 \mathrm{~s}$ was required. The external standard (a NIST-612 glass) was analysed after every five sample measurements. Raw counts were reduced using GLITTER (developed by GEMOC and CSIRO) with ${ }^{29} \mathrm{Si}$ as internal standard. A mixed Ar-He stream was used to carry the ablated material into a Thermo Finnigan Element 2 inductively coupled plasmamass spectrometer.

TEM investigations were carried out with a JEOL 3010 TEM operating at $300 \mathrm{kV}$. Conventional bright-field images and diffraction patterns were taken on photo negative films. Electron transparent foils for the TEM investigation were cut from polished grains by a focused ion beam (FIB) using a 1540 XB CrossBeam ${ }^{\circledR}$.

\section{Starting material}

Natural, optically clear crystals (gem-quality) of oligoclase from Minas Gerais (Brazil) and labradorite from Nuevo Casas Grande, Chihuahua (Mexico) were used as starting material for the hydrothermal experiments. Major and minor element concentrations of the unaltered oligoclase and labradorite crystals were determined by averaging 10 EMP measurements in each case (Table 1). The concentrations (wt $\%$ oxide) were normalised to 5 cations and converted into molar percentages of the pure $\mathrm{Na}-, \mathrm{Ca}-$ and K-feldspar components albite (Ab), anorthite (An) and orthoclase (Or), respectively. The original oligoclase is composed of the major element oxides $\mathrm{SiO}_{2}, \mathrm{Al}_{2} \mathrm{O}_{3}, \mathrm{CaO}$ and $\mathrm{Na}_{2} \mathrm{O}$ and contains minor concentrations in $\mathrm{K}_{2} \mathrm{O}$ and $\mathrm{FeO}$. Its feldspar composition corresponds to $\mathrm{Ab}_{73} \mathrm{An}_{23} \mathrm{Or}_{4}$. The pristine labradorite has comparatively higher $\mathrm{Al}_{2} \mathrm{O}_{3}$ and $\mathrm{CaO}$ but lower $\mathrm{SiO}_{2}$ and $\mathrm{Na}_{2} \mathrm{O}$ concentrations according to a composition of approximately $\mathrm{Ab}_{39} \mathrm{An}_{60} \mathrm{Or}_{1}$. Minor element oxides in the labradorite are $\mathrm{FeO}, \mathrm{K}_{2} \mathrm{O}$, $\mathrm{TiO}_{2}$ and $\mathrm{MgO}$.

Representative trace element analyses of the pristine oligoclase and labradorite crystals are reported in Table 2. All analyses were carried out under the same conditions. The difference in the initial trace element composition of oligoclase and labradorite manifests itself most clearly in the concentrations of $\mathrm{Ti}$ and $\mathrm{Pb}$. While $\mathrm{Ti}$ is not detectable in the oligoclase, it is consistently present in the labradorite. In contrast, $\mathrm{Pb}$ is present in the oligoclase but not in the labradorite. Concentrations in $\mathrm{Mg}, \mathrm{Sr}, \mathrm{Y}, \mathrm{Ba}, \mathrm{La}, \mathrm{Ce}, \mathrm{Pr}$ and $\mathrm{Nd}$ are lower in oligoclase, whereas the contents of $\mathrm{Rb}$, $\mathrm{Sm}$ and $\mathrm{Eu}$ are lower in labradorite. Concentrations of heavy rare earth elements (HREEs: Gd-Lu) are mostly below the detection limit in both plagioclases.

\section{Experimental procedures}

Cleaved fragments of each sample were ground and sieved to produce crystal powders with grain sizes ranging from 100 to $200 \mu \mathrm{m}$. Subsequently, the powder was thoroughly washed in deionised water and dried in an oven at $100^{\circ} \mathrm{C}$. For each experiment approximately $15 \mathrm{mg}$ of the powdered starting material was filled into a gold capsule (inner diameter: $2.8 \mathrm{~mm}$; length: $2.5 \mathrm{~cm}$ ). To provide an excess of $\mathrm{Na}^{+}$and $\mathrm{Si}^{4+}$ during the experiments approximately $30 \mathrm{mg}$ of a 1:1 mixture of sodium silicate solution (reagent grade, based on $13.8 \% \mathrm{NaOH}, 25.9 \% \mathrm{SiO}_{2}$ and $60.3 \% \mathrm{H}_{2} \mathrm{O}$ ) and deionised water was added. The measured $\mathrm{pH}$ of this fluid at room temperature was $\sim 12$. The $\mathrm{pH}$ at experimental temperature is decreased to a value of about 9 (according to an extrapolation of data from Hellmann 1994). The total $\mathrm{Na}$ (fluid): $\mathrm{Ca}$ (solid) ratios for an oligoclase or labradorite 
Table 1 Major and minor element concentrations of the starting material and the albite product

\begin{tabular}{|c|c|c|c|c|c|c|c|c|c|c|}
\hline \multirow[t]{2}{*}{ wt $\%$} & \multicolumn{2}{|c|}{ Oligoclase } & \multicolumn{3}{|c|}{ Albite rim } & \multicolumn{2}{|c|}{ Labradorite } & \multicolumn{3}{|c|}{ Albite rim } \\
\hline & Avg. ${ }^{\mathrm{a}}$ & $1 \sigma$ & Avg. ${ }^{a}$ & $1 \sigma$ & $\%$ Change $^{\mathrm{b}}$ & Avg. ${ }^{a}$ & $1 \sigma$ & Avg. ${ }^{a}$ & $1 \sigma$ & $\%$ Change $^{\mathrm{b}}$ \\
\hline $\mathrm{SiO}_{2}$ & 62.8 & 0.2 & 68.9 & 0.1 & +8.6 & 53.1 & 0.2 & 69.1 & 0.4 & +26.8 \\
\hline $\mathrm{TiO}_{2}$ & $<0.01$ & & $<0.01$ & & & 0.1 & 0.03 & $<0.01$ & & -100.0 \\
\hline $\mathrm{Al}_{2} \mathrm{O}_{3}$ & 23.8 & 0.2 & 19.9 & 0.08 & -17.1 & 29.8 & 0.2 & 20.0 & 0.1 & -34.9 \\
\hline $\mathrm{FeO}$ & 0.1 & 0.03 & $<0.01$ & & -100.0 & 0.3 & 0.02 & 0.2 & 0.08 & -48.9 \\
\hline $\mathrm{MnO}$ & $<0.01$ & & $<0.01$ & & & $<0.01$ & & $<0.01$ & & \\
\hline $\mathrm{MgO}$ & $<0.01$ & & $<0.01$ & & & 0.1 & 0.01 & $<0.01$ & & -100.0 \\
\hline $\mathrm{CaO}$ & 4.7 & 0.06 & 0.02 & 0.01 & -99.7 & 12.2 & 0.1 & 0.06 & 0.06 & -99.5 \\
\hline $\mathrm{Na}_{2} \mathrm{O}$ & 8.4 & 0.3 & 11.6 & 0.2 & +36.5 & 4.4 & 0.1 & 11.5 & 0.3 & +155.0 \\
\hline $\mathrm{K}_{2} \mathrm{O}$ & 0.7 & 0.04 & 0.1 & 0.03 & -87.6 & 0.3 & 0.02 & 0.03 & 0.01 & -87.4 \\
\hline Total & 100.4 & & 100.6 & & & 100.3 & & 100.8 & & \\
\hline \multicolumn{11}{|c|}{ Structural formula based on 5 cations } \\
\hline $\mathrm{Si}$ & 2.77 & & 2.99 & & & 2.40 & & 2.99 & & \\
\hline $\mathrm{Al}$ & 1.24 & & 1.02 & & & 1.59 & & 1.02 & & \\
\hline $\mathrm{Ca}$ & 0.22 & & 0.00 & & & 0.59 & & 0.00 & & \\
\hline $\mathrm{Na}$ & 0.72 & & 0.98 & & & 0.38 & & 0.96 & & \\
\hline $\mathrm{K}$ & 0.04 & & 0.005 & & & 0.01 & & 0.002 & & \\
\hline \multicolumn{11}{|c|}{ Mol\% feldspar component } \\
\hline An & 22.57 & & $<0.001$ & & & 59.67 & & $<0.001$ & & \\
\hline $\mathrm{Ab}$ & 73.46 & & 99.51 & & & 38.83 & & 99.81 & & \\
\hline Or & 3.97 & & 0.49 & & & 1.49 & & 0.19 & & \\
\hline
\end{tabular}

${ }^{a}$ Averages are based on 10 measurements

b Relative changes are based on mass balance calculations (see text)

run were approximately 5:1 and 2:1, respectively, and the $\mathrm{Si}$ (fluid):Al(solid) ratios were approximately $1: 1$ for both oligoclase and labradorite experiments. According to the simplified model exchange reaction $\mathrm{CaAl}_{2} \mathrm{Si}_{2} \mathrm{O}_{8}+\mathrm{Na}^{+}$ $+\mathrm{Si}^{4+} \leftrightarrow \mathrm{NaAlSi}_{3} \mathrm{O}_{8}+\mathrm{Al}^{3+}+\mathrm{Ca}^{2+}$, the $\mathrm{Na}^{+}$and $\mathrm{Si}^{4+}$ excess in each experimental run was theoretically high enough to completely convert the amount of plagioclase in the capsule into albite. The capsules were sealed by laser beam welding and then loaded into standard horizontally mounted cold-seal pressure vessels. The hydrothermal experiments were performed at $600^{\circ} \mathrm{C}$ and $2 \mathrm{kbars}$ and the experimental duration was either 14 or 21 days. The system was heated from room temperature to $600 \pm 1^{\circ} \mathrm{C}$ within $2 \mathrm{~h}$. Water was used as the external pressure medium to maintain a pressure of 2 kbars. On termination of the experiments the pressure was released while the system was cooled down in an air stream to room temperature within $20 \mathrm{~min}$. The capsules were then opened and the sample was removed and dried in an oven at $100^{\circ} \mathrm{C}$ overnight.

A similar experiment was carried out using an ${ }^{18} \mathrm{O}$ enriched solution. For this purpose the capsule was filled with $19.18 \mathrm{mg}$ of ${ }^{18} \mathrm{O}$-enriched water $\left({ }^{16} \mathrm{O}=1.8 \%\right.$; ${ }^{17} \mathrm{O}=0.3 \% ;{ }^{18} \mathrm{O}=97.9 \%$, obtained from Campro Scientific, Netherlands) and $12.38 \mathrm{mg}$ of the sodium silicate solution. The resulting solution contained approximately
$62 \%{ }^{18} \mathrm{O}$. An amount of $19.79 \mathrm{mg}$ of oligoclase powder was allowed to react with this fluid.

The experimental run products were divided for further analytical work. One part of the sample material was embedded into epoxy and polished to make cross sections through the grains. These polished grain mounts were used for back-scattered electron (BSE) imaging by SEM, for quantitative major and minor element measurements by EMP, for trace element analyses by LA-ICP-MS, and for micro-Raman spectroscopic analyses. Samples for TEM were also prepared from polished grain mounts. In order to observe the crystal surfaces some grains were fixed onto aluminium stubs with Leit-C tabs for SE imaging by SEM. The samples were carbon coated before SEM and EMP analyses.

\section{Results}

Optical and textural characteristics of the reaction products

After experimental treatment, the appearance of the sample crystals changed from optically clear to turbid. However, the size of the crystal grains did not change. SEM surface 
Table 2 Representative LAICP-MS analyses of the starting material and the albite product

Relative changes are based on mass balance calculations (see text)

\begin{tabular}{|c|c|c|c|c|c|c|}
\hline ppm & Oligoclase & Albite rim & $\%$ Change $^{a}$ & Labradorite & Albite rim & $\%$ Change \\
\hline $\mathrm{Mg}$ & 12 & $<3.53$ & $>-71$ & 737 & 3.6 & -99 \\
\hline $\mathrm{Ti}$ & $<17.01$ & $<18.25$ & & 415 & $<15.59$ & $>-96$ \\
\hline $\mathrm{Rb}$ & 2.3 & $<0.181$ & $>-92$ & 0.25 & $<0.166$ & $>-35$ \\
\hline $\mathrm{Sr}$ & 693 & 22 & -97 & 781 & 18 & -97 \\
\hline Y & 0.11 & $<0.001$ & $>-99$ & 0.19 & $<0.001$ & $>-99$ \\
\hline $\mathrm{Ba}$ & 68 & 1.1 & -98 & 101 & 1.2 & -98 \\
\hline $\mathrm{La}$ & 0.31 & $<0.001$ & $>-99$ & 1.2 & $<0.001$ & $>-99$ \\
\hline $\mathrm{Ce}$ & 0.36 & $<0.001$ & $>-99$ & 2.2 & $<0.001$ & $>-99$ \\
\hline $\operatorname{Pr}$ & 0.022 & 0.0059 & $>-73$ & 0.18 & 0.0044 & -97 \\
\hline $\mathrm{Nd}$ & 0.079 & $<0.001$ & $>-99$ & 1.1 & 0.026 & -97 \\
\hline $\mathrm{Sm}$ & 0.031 & $<0.001$ & $>-97$ & $<0.001$ & $<0.001$ & \\
\hline $\mathrm{Eu}$ & 0.96 & $<0.001$ & $>-99$ & 0.37 & 0.0058 & -98 \\
\hline Gd & 0.03 & $<0.001$ & $>-97$ & $<0.001$ & $<0.001$ & \\
\hline $\mathrm{Tb}$ & $<0.001$ & $<0.001$ & & 0.0064 & $<0.001$ & $>-84$ \\
\hline Dy & $<0.001$ & $<0.001$ & & 0.027 & $<0.001$ & $>-96$ \\
\hline Ho & 0.0046 & $<0.001$ & $>-79$ & $<0.001$ & $<0.001$ & \\
\hline $\mathrm{Er}$ & $<0.001$ & $<0.001$ & & 0.059 & $<0.001$ & $>-98$ \\
\hline $\mathrm{Tm}$ & $<0.001$ & $<0.001$ & & $<0.001$ & $<0.001$ & \\
\hline $\mathrm{Yb}$ & $<0.001$ & $<0.001$ & & $<0.001$ & $<0.001$ & \\
\hline $\mathrm{Lu}$ & $<0.001$ & $<0.001$ & & $<0.001$ & $<0.001$ & \\
\hline $\mathrm{Pb}$ & 35 & $<0.23$ & $>-99$ & $<0.202$ & $<0.170$ & \\
\hline
\end{tabular}

images reveal a high porosity and roughness of the reacted material compared to the unreacted grains, which have flat and smooth surfaces without any visible porosity (Fig. 1). Larger pores are often filled with needle shaped crystals of pectolite $\left(\mathrm{NaCa}_{2} \mathrm{Si}_{3} \mathrm{O}_{8} \mathrm{OH}\right)$. In nature, pectolite is a typical hydrothermal mineral which occurs in cavities and joint planes in basic igneous rocks and is common in metamorphosed high calcium rocks and skarns (Deer et al. 1992). It could clearly be identified by Raman spectroscopy from polished cross sections.

BSE images and combined EDX analyses of cross sections throughout the crystals indicate pseudomorphic replacement of the original plagioclase by an albite-rich feldspar composition (Fig. 2). The replacement advanced from the grain surfaces and along pre-existing cracks inwards into the crystal, so that the product albite is located in a rim around the parent plagioclase. However, the width of the reaction rim varies strongly from grain to grain and even within a single grain, but there are no significant differences of the average rim widths when comparing the 14 day experiments with the 21 day experiments (Fig. 2a, c).

In some parts of partly replaced labradorite crystals (Fig. 2d), there are zones at the boundary between the original labradorite and the product albite, which show a different, more complex texture with numerous large pores. Although it could not be verified by Raman spectroscopy,
BSE images with higher magnification (Fig. 2e) suggest that these zones are composed of an intergrowth between pectolite + albite and/or labradorite.

Pectolite grains are mostly $1-5 \mu \mathrm{m}$ in diameter and appear as the brightest phase in BSE images. They are commonly located in surface notches of the reacted plagioclase grains. Occasionally, they are distributed within the reaction rims. In addition, a very dark phase in BSE images is present in all run products in varying amounts and often associated with pectolite (Fig. 2f). Raman spectroscopy failed to identify this as a crystalline phase. The fact that it is extremely sensitive to the electron beam and has an undefined shape with numerous open cracks, suggests that it is an amorphous phase that is similar to anhydrous sodium silicate (known as water glass). Such an amorphous phase could have formed through the dehydration of the residual fluid during the drying procedure of the sample after experimental treatment. To test this hypothesis a blank was prepared by drying a few drops of the initial sodium silicate solution in the same way as the reacted material. The solid product was observed under the SEM and revealed very similar textures, thus, confirming our interpretation. Chemical analyses of this amorphous phase proved to be very useful for monitoring the change of the fluid composition during the reaction. 
Fig. 1 a, b SEM surface images of an unreacted oligoclase compared to $\mathbf{c}, \mathbf{d}$ a reacted oligoclase grain from a 21 day experiment; $\mathbf{b}$ and $\mathbf{d}$ are images with higher

magnification showing the areas outlined by white rectangles in a and $\mathbf{c}$, respectively. Note that the unreacted material shows flat cleavage surfaces and no evidence for porosity, whereas the reaction products are rough with numerous pores which are often filled with needle shaped crystals of pectolite
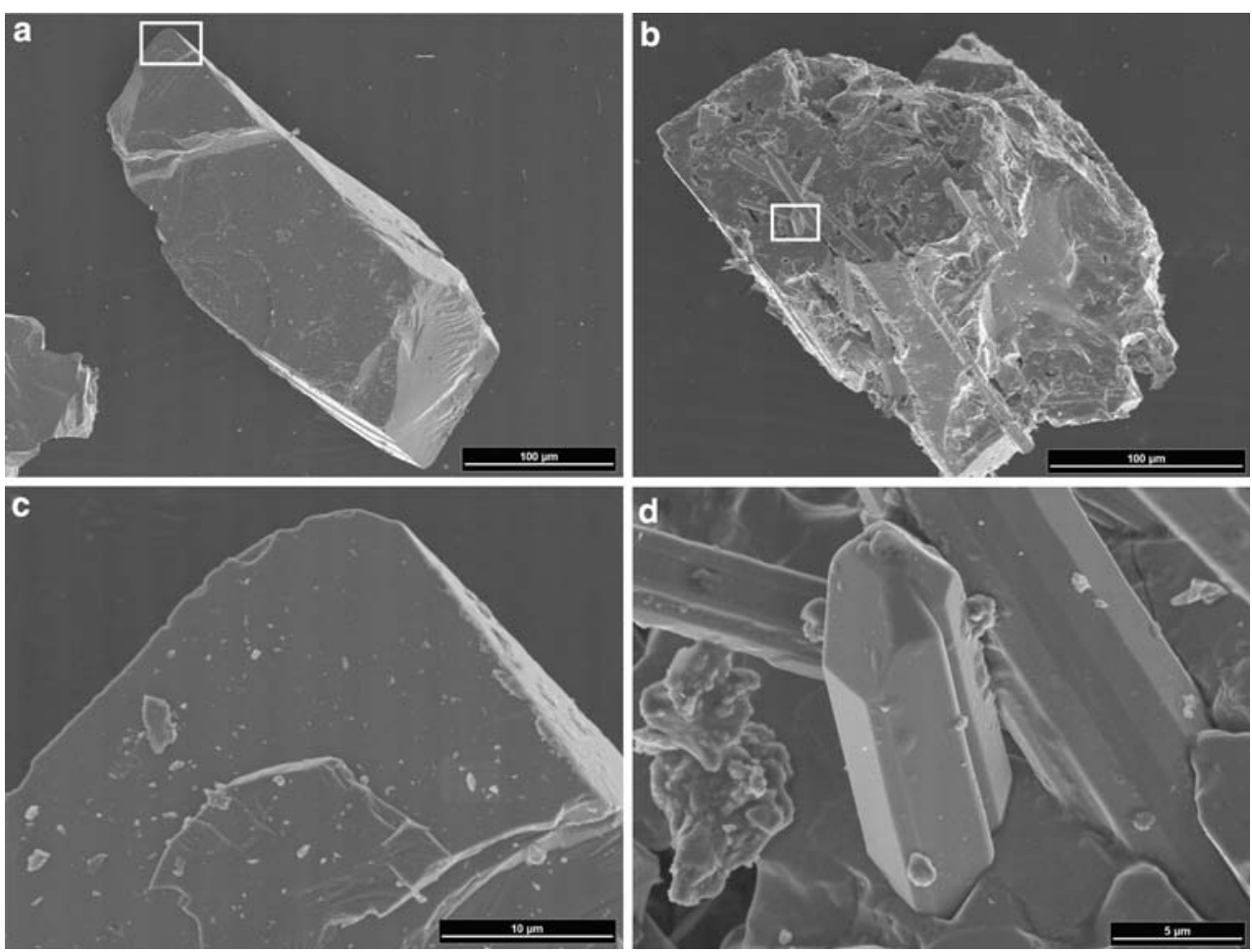

Chemical composition of the reaction products

The replacement product of both oligoclase and labradorite is nearly pure albite $\left(\mathrm{Ab}_{99-100} \mathrm{Or}_{0-1}\right)$, although minor concentrations in $\mathrm{K}_{2} \mathrm{O}$ or $\mathrm{FeO}$ could be detected in case of altered oligoclase or labradorite, respectively (Table 1).

EMP line scans across the interface of a partly replaced oligoclase grain (Fig. 3a) were performed to investigate the sharpness of the chemical interface. Profiles of molar fractions of albite and anorthite show that the major compositional change is sharp on a micrometer scale (Fig. 3b). Elemental distribution maps of $\mathrm{Si}, \mathrm{Al}, \mathrm{Ca}$ and $\mathrm{Na}$ demonstrate that the albite reaction zones are chemically homogenous (Figs. 3c-f). Unfortunately, it was not possible to carry out accurate measurements with spatial resolution higher than $3 \mu \mathrm{m}$ as the albite is very sensitive to damage under the electron beam. Using a step size of $1 \mu \mathrm{m}$ for line scans led to an intense volatilisation of $\mathrm{Na}$ (and $\mathrm{K}$ ) in the excited sample volume even at reduced counting times. This effect markedly increased in the product phase. Therefore, a step size of $3 \mu \mathrm{m}$ was used, resulting in line profiles that do not display the real sharpness of the chemical interface.

The albite rims around both oligoclase and labradorite contain no detectable trace elements except for $\mathrm{Sr}, \mathrm{Ba}$ and some light rare earth elements (LREEs: La-Eu) such as Pr, $\mathrm{Nd}$ and Eu (Table 2). In case of analysis of the albite rim around labradorite special attention was paid to avoid the intergrowth zones (Fig. 2e). The concentrations of the detected trace elements in the albites formed around oligoclase and labradorite are significantly lower compared to the unaltered plagioclases, but are approximately equal in both albites.

The major and minor element concentrations of secondary pectolite are given in Table 3 and represent averages of 10 measurements. As minor elements were not detectable the composition corresponds to nearly pure $\mathrm{NaCa}_{2} \mathrm{Si}_{3} \mathrm{O}_{8} \mathrm{OH}$.

Single EMP analyses of the amorphous phases associated with either the oligoclase or the labradorite reaction products, as well as of the amorphous phase that was prepared as a blank from the starting solution, are also reported in Table 3. These measurements were performed using a strongly defocused electron beam $(20-30 \mu \mathrm{m})$ as these phases are extremely sensitive to heating due to electron bombardment. The analyses should be regarded as semi-quantitative as even with this defocused electron beam volatilisation effects during measurement were unavoidable. Furthermore, it must be emphasised that the reported values do not represent a general composition as it is obvious from BSE images that the amorphous phases are not chemically homogeneous and often show diffusive transitions (Fig. 2f). Nevertheless, the data are sufficient to provide some qualitative information. The main constituents of the amorphous phases associated with oligoclase and labradorite are $\mathrm{SiO}_{2}, \mathrm{Al}_{2} \mathrm{O}_{3}, \mathrm{Na}_{2} \mathrm{O}$ and volatiles (most likely $\mathrm{H}_{2} \mathrm{O}$ ). $\mathrm{TiO}_{2}, \mathrm{FeO}, \mathrm{MgO}, \mathrm{CaO}$ and $\mathrm{K}_{2} \mathrm{O}$ are present in minor concentrations in the amorphous phase formed from a labradorite experiment. Its equivalent from an oligoclase experiment contains minor concentrations of $\mathrm{FeO}, \mathrm{CaO}$ and 

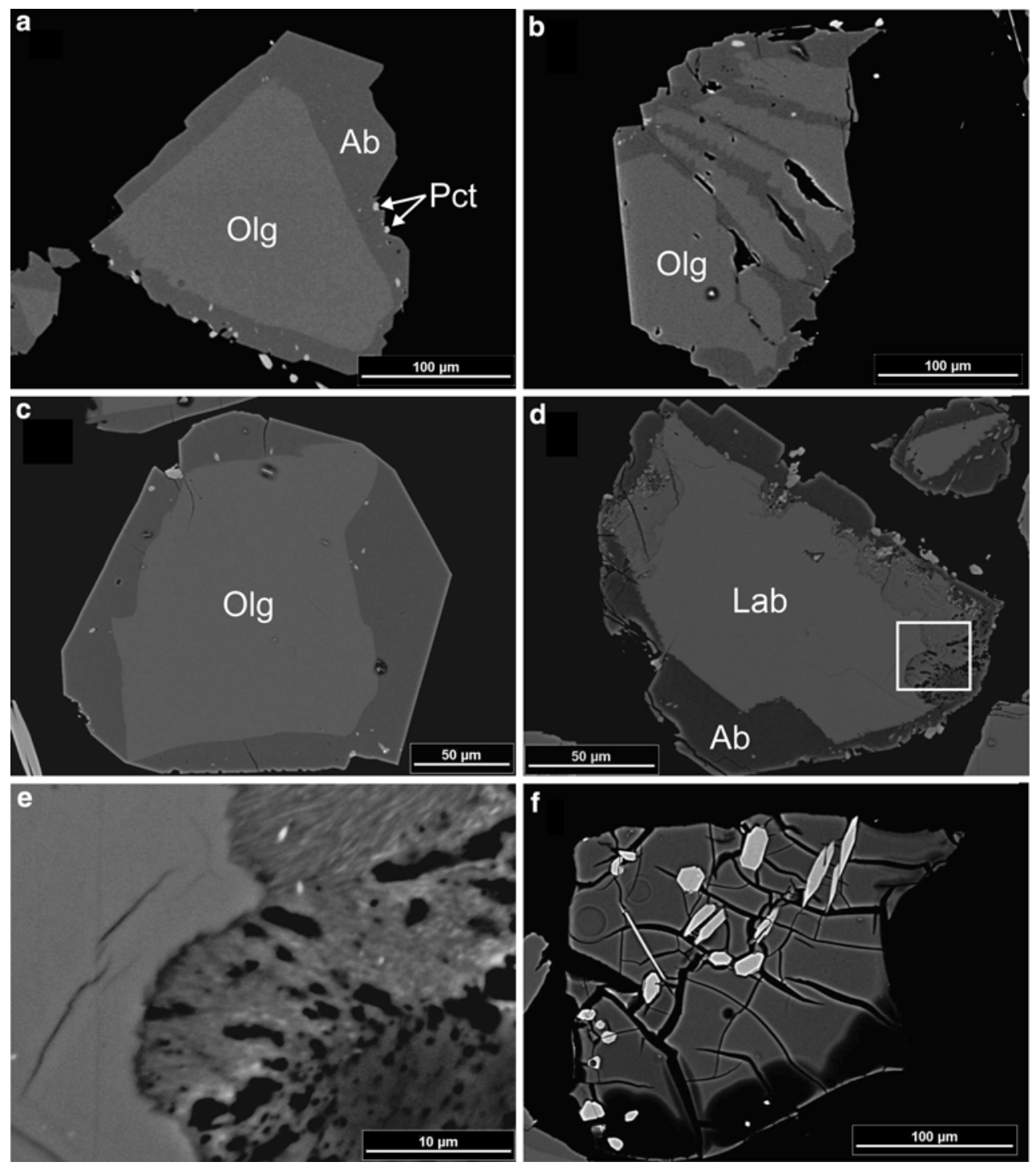

Fig. 2 BSE images of cross sections throughout the reaction products showing oligoclase $(\mathrm{Olg})$ and labradorite $(\mathrm{Lab})$ crystals partly replaced by albite $(A b)$. Bright grains are pectolite $(P c t)$. a, b Partly albitised oligoclase grains from a 21 day experiment. c Reacted oligoclase grain from a 14 day experiment. d Partly albitised

labradorite grain from a 21 day experiment. e Close-up of the area marked with a white rectangle in $\mathbf{d}$. f Amorphous phase in a sample from an oligoclase experiment associated with numerous pectolite grains

$\mathrm{K}_{2} \mathrm{O}$. In contrast, the blank mainly comprises $\mathrm{SiO}_{2}, \mathrm{Na}_{2} \mathrm{O}$ and $\mathrm{H}_{2} \mathrm{O}$, but does not contain $\mathrm{Al}_{2} \mathrm{O}_{3}$ and has lower concentrations of other minor elements.

Unfortunately, the pectolite grains were too small to be measured precisely by LA-ICP-MS. Thus, Table 4 only contains representative analyses of the amorphous phases. The amorphous phase prepared from the starting solution consistently contains almost all of the analysed trace elements. This indicates a high variety of impurities in the initial sodium silicate solution. The measured values are between 0.1 and $1 \mathrm{ppm}$ for $\mathrm{Rb}, \mathrm{Pb}$ and most of the REEs. $\mathrm{Mg}, \mathrm{Sr}, \mathrm{Y}$ and $\mathrm{Ba}$ were found in concentrations between 1 and $10 \mathrm{ppm}$. The highest concentration was measured for

Ti (58 ppm). However, the data reveal that the concentrations of $\mathrm{Mg}, \mathrm{Ti}, \mathrm{Rb}, \mathrm{Sr}, \mathrm{Ba}, \mathrm{La}, \mathrm{Ce}, \mathrm{Eu}$ and $\mathrm{Pb}$ are significantly increased in the amorphous phases from either oligoclase or labradorite experiments. Furthermore, it is noticeable that the ratios of trace element concentrations of the initial plagioclases are generally reflected within these phases when comparing the values among each other. For instance, $\mathrm{Ti}$ was not detected in the oligoclase but is present in the labradorite. By analogy, the amorphous phase from an oligoclase experiment has a 10 times lower Ti-concentration compared to its counterpart from a labradorite experiment. Similar relations are also noticeable for $\mathrm{Mg}, \mathrm{Rb}, \mathrm{Sr}, \mathrm{Y}, \mathrm{Ba}, \mathrm{La}, \mathrm{Ce}, \mathrm{Nd}, \mathrm{Eu}$ and $\mathrm{Pb}$. 
Fig. 3 a BSE image of a partly albitised oligoclase grain that was chosen for an EMP line scan and element mapping. The direction of the line scan is indicated by the white line. b Profile of the molar concentration of the albite and anorthite component. Note the major compositional changes at the interface. The altered part of the crystal is chemically homogeneous and consists of nearly pure albite in comparison to the intermediate composition of the unaltered part.

c-f Elemental distribution maps of $\mathrm{Si}, \mathrm{Al}, \mathrm{Na}$ and $\mathrm{Ca}$, respectively. The sharp compositional interface and the lack of any chemical zoning within the altered part are again obvious. Note that areas showing a higher

Ca-concentration within the albite rim correspond to the pectolite grains visible from the BSE image in a
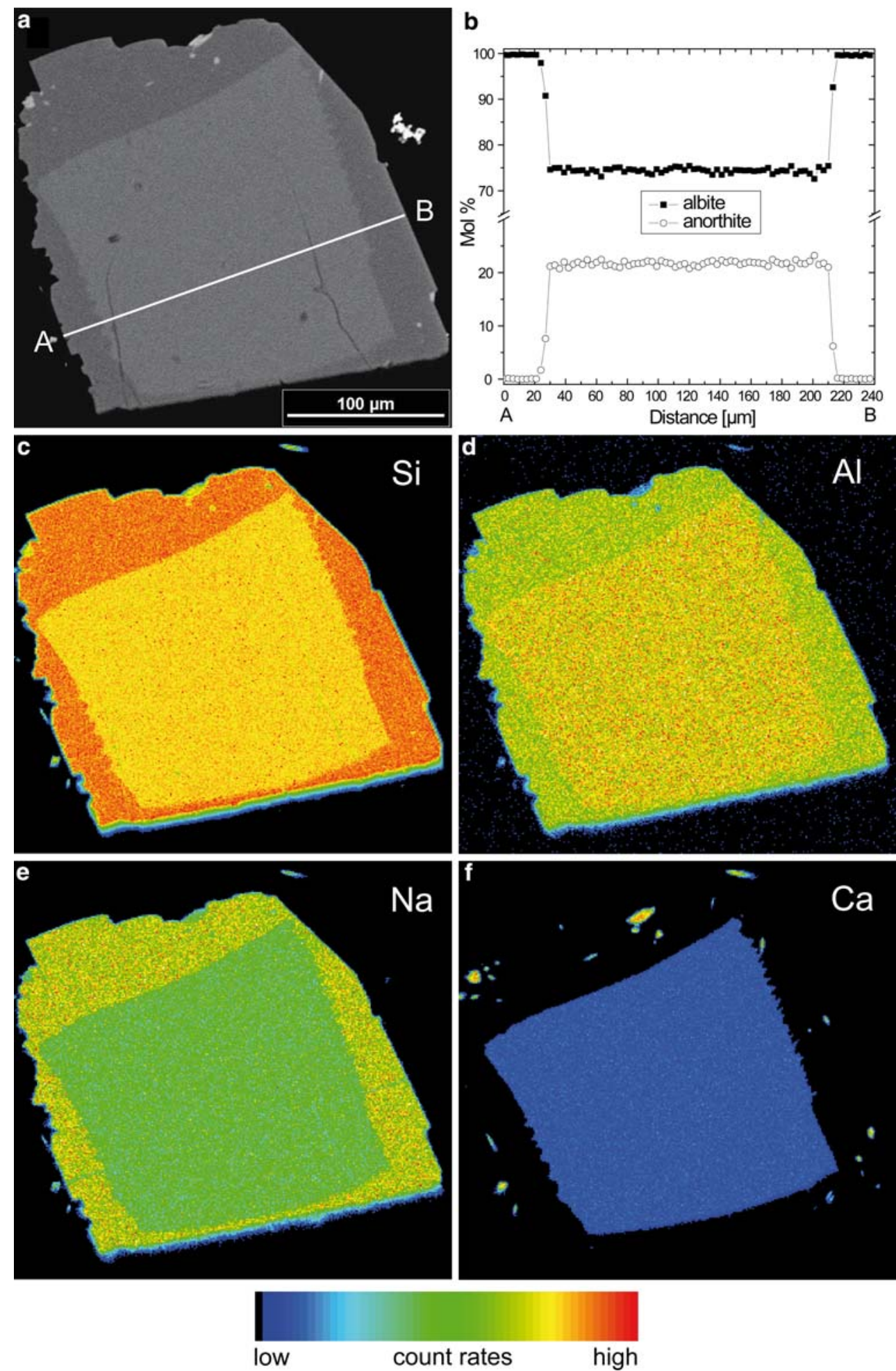

Mass balance calculations

The relative losses and gains of major, minor and trace elements accompanying the albitisation of oligoclase and labradorite can be calculated using Gresens' composition- volume relationships of metasomatism (Gresens 1967). Regarding the feldspar crystals, a constant volume can be assumed according to the evidence of pseudomorphism. The hypothetical composition of albite $C_{\mathrm{hyp}}^{\mathrm{Ab}}$ is then calculated from the relationship: 
Table 3 Major and minor element concentrations of pectolite and the amorphous phases a Averages are based on 10 measurements

b Single measurements

\begin{tabular}{|c|c|c|c|c|c|}
\hline \multirow[t]{2}{*}{ wt $\%$} & \multicolumn{2}{|c|}{ Pectolite } & \multicolumn{3}{|c|}{ Amorphous phases } \\
\hline & Avg. ${ }^{\mathrm{a}}$ & $1 \sigma$ & $\begin{array}{l}\text { Oligoclase } \\
\text { experiment }^{\mathrm{b}}\end{array}$ & $\begin{array}{l}\text { Labradorite } \\
\text { experiment }{ }^{\mathrm{b}}\end{array}$ & Blank $^{\mathrm{b}}$ \\
\hline $\mathrm{SiO}_{2}$ & 54.2 & 0.3 & 68.1 & 62.0 & 65.6 \\
\hline $\mathrm{TiO}_{2}$ & $<0.01$ & & 0.05 & 0.2 & $<0.01$ \\
\hline $\mathrm{Al}_{2} \mathrm{O}_{3}$ & $<0.01$ & & 10.5 & 10.1 & 0.02 \\
\hline $\mathrm{FeO}$ & 0.04 & 0.03 & 0.1 & 0.5 & 0.07 \\
\hline $\mathrm{MnO}$ & $<0.01$ & & $<0.01$ & 0.04 & $<0.01$ \\
\hline $\mathrm{MgO}$ & $<0.01$ & & $<0.01$ & 0.2 & 0.01 \\
\hline $\mathrm{CaO}$ & 33.1 & 0.3 & 0.7 & 1.0 & 0.3 \\
\hline $\mathrm{Na}_{2} \mathrm{O}$ & 9.3 & 0.3 & 6.1 & 9.3 & 12.0 \\
\hline $\mathrm{K}_{2} \mathrm{O}$ & $<0.01$ & & 1.5 & 0.4 & 3.7 \\
\hline Total & 96.64 & & 87.1 & 83.7 & 81.7 \\
\hline
\end{tabular}

densities used for the calculations are $2.62 \mathrm{~g} / \mathrm{cm}^{3}$ for albite, $2.65 \mathrm{~g} / \mathrm{cm}^{3}$ for oligoclase and $2.69 \mathrm{~g} / \mathrm{cm}^{3}$ for labradorite (taken from Deer et al. 1992). The calculated values for major and minor elements and for trace elements are given in Tables 1 and 2, respectively. Minimum changes are reported in cases where the element concentrations in the albitised parts are below the detection limit. Due to the assumption of constant volume during albitisation, the data consequently record considerable losses of $\mathrm{Al}_{2} \mathrm{O}_{3}$ and $\mathrm{CaO}$ and gains of $\mathrm{SiO}_{2}$ and $\mathrm{Na}_{2} \mathrm{O}$. Furthermore, it is noticeable that all minor and trace elements detected in the original plagioclases were almost completely lost. This is depicted in an isocon diagram (Fig. 4), which is the graphical solution to Gresens' composition-volume relationships (Grant 1986). The lost elements plot below the constant volume isocon which has a slope equal to $\left(\rho^{\mathrm{Plg}} / \rho^{\mathrm{Ab}}\right)$, whereas gained elements, e.g. $\mathrm{SiO}_{2}$ and $\mathrm{Na}_{2} \mathrm{O}$, plot above.

The microstructure at the reaction interface

The microstructure at the replacement interface was investigated by TEM. Figure 5 shows bright-field TEM images of a FIB foil that was cut perpendicular to an albite-oligoclase interface. It is obvious that the product albite shows a remarkably different diffraction contrast compared to the original plagioclase. While the contrast is uniform and smooth in the unaltered part, the altered part is characterised by a complex, dense and dark structure indicating a much higher defect density. It is noteworthy that these features are similar to those reported from naturally albitised plagioclase (Engvik et al. 2008). A comparison of electron diffraction patterns from the unaltered and altered parts as well as from the interface region (Figs. 5d-f) demonstrates that the crystallographic orientation of the oligoclase was inherited by the albite during the replacement process. The diffraction spots of the three patterns coincide almost perfectly showing that the crystal 


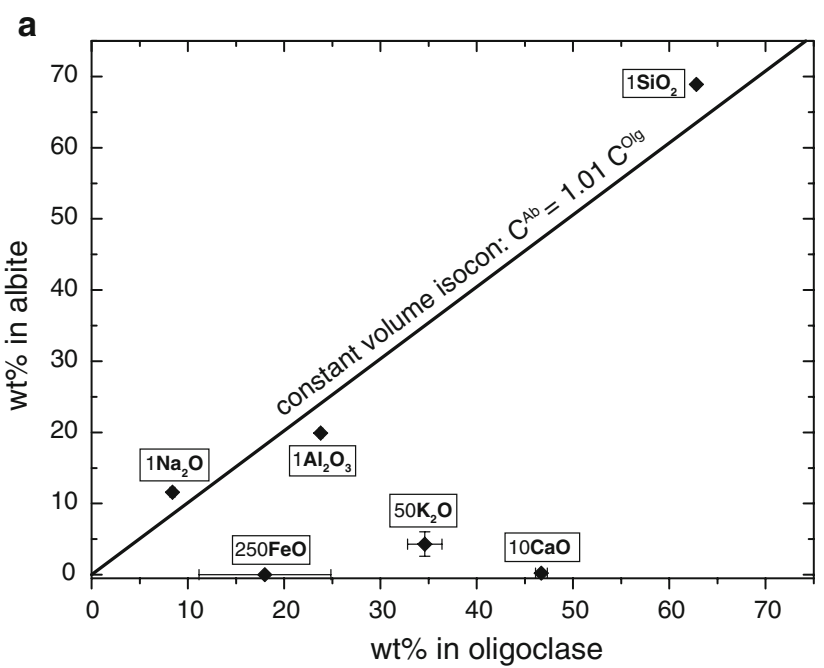

C

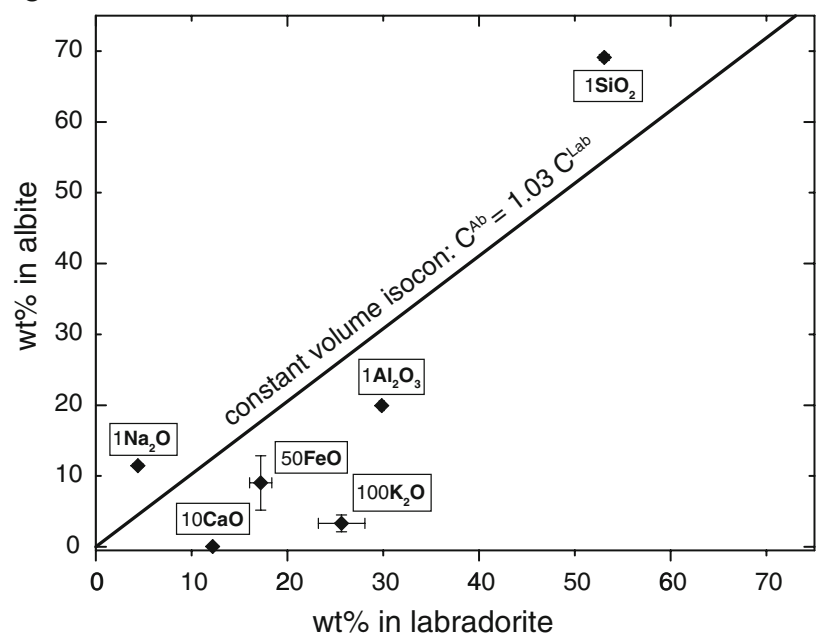

Fig. 4 Isocon diagrams demonstrating losses and gains of major, minor and trace elements. The element concentrations in the altered parts are plotted against the element concentrations in the unaltered parts. The isocon defines a straight line with a slope equal to the density ratio $\left(\rho^{\mathrm{Plg}} / \rho^{\mathrm{Ab}}\right)$ when constant volume during albitisation is assumed. Lost elements plot below and gained elements plot above the isocon. a Major and minor element and $\mathbf{b}$ trace element isocon

misorientation between the oligoclase and the albite is below one degree.

\section{Results of the ${ }^{18} \mathrm{O}$ tracer experiment}

We used Raman spectroscopy to test whether the albite formed in the ${ }^{18} \mathrm{O}$-enriched solution contains ${ }^{18} \mathrm{O}$ in the framework. This technique allows for the direct detection of ${ }^{18} \mathrm{O}$ in the framework structure of albite because the incorporation of the heavier ${ }^{18} \mathrm{O}$-isotope leads to a decrease of the frequency of those vibrational modes that involve motions of oxygen atoms.
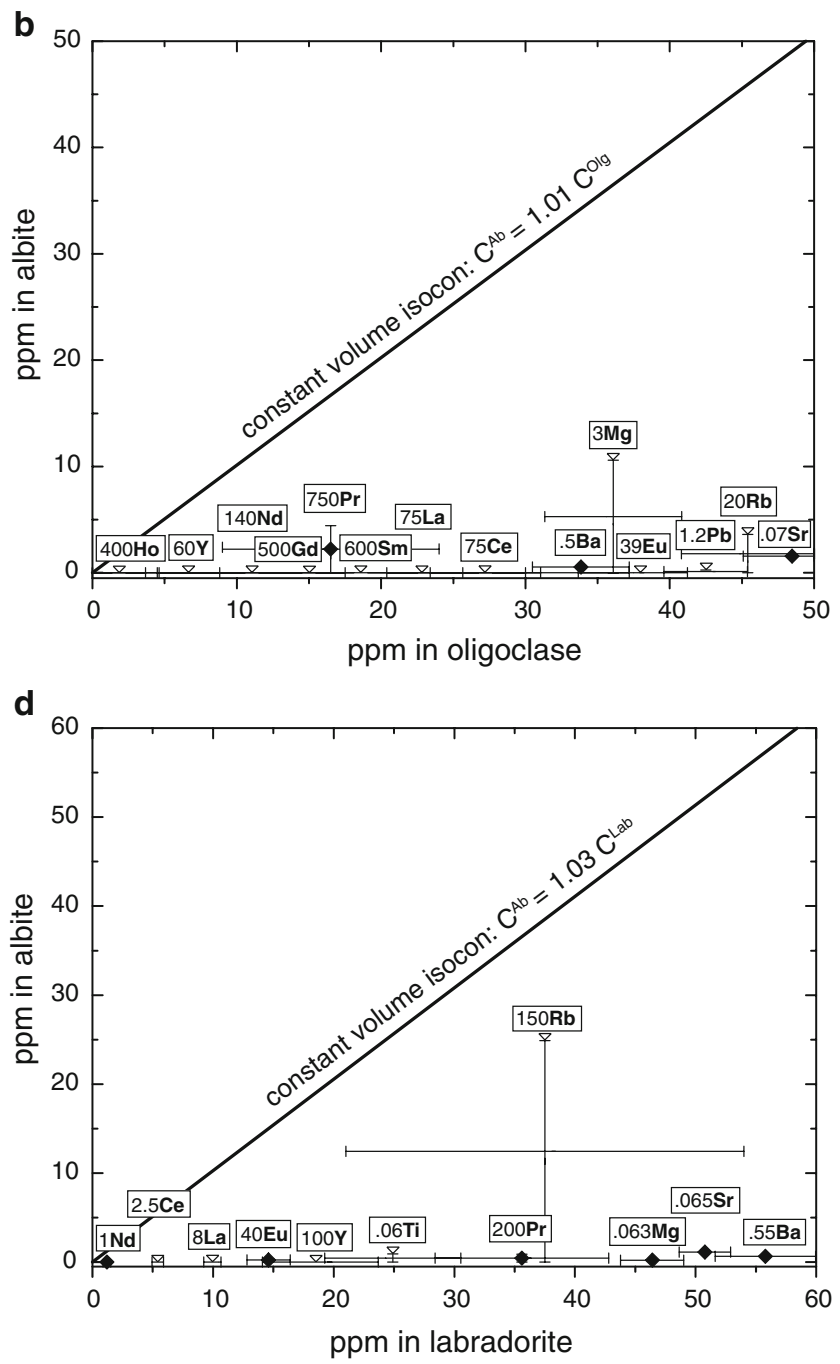

plot for albitised oligoclase. c Major and minor element and $\mathbf{d}$ trace element isocon plot for albitised labradorite. Error bars are $1 \sigma$ standard deviations. For elements that were not detectable in the albitised parts no points are plotted and bars with open triangles indicate the detection limit. Numbers before element symbols indicate the scaling factor used for the plot. Note the massive losses of all analysed trace elements

Natural albite shows two prominent Raman bands near 509 and $479 \mathrm{~cm}^{-1}$, which were assigned to O-T-O bending and stretching vibrations of the four-membered tetrahedral rings (McKeown 2005). Seven measurements on albite formed in "normal" fluid yielded averages of $508.9( \pm 0.5)$ and $478.5( \pm 0.4) \mathrm{cm}^{-1}$ for these modes. A representative Raman spectrum obtained from an albite formed in the ${ }^{18} \mathrm{O}$-enriched solution displays shifts of about -13 and $-10 \mathrm{~cm}^{-1}$, respectively, indicating a high amount of ${ }^{18} \mathrm{O}$ in the framework structure (Fig. 6). Kieffer (1982) has suggested that the O-T-O bending modes in albite shift by a factor of 0.961462 to lower frequencies if all ${ }^{16} \mathrm{O}$ are 
Fig. 5 a BSE image of a partly albitised oligoclase grain

indicating the location where a FIB cut was performed (white rectangle). b TEM bright-field image of the sampled TEM foil. A detailed image of the area outlined by the white rectangle is shown in $\mathbf{c}$. The altered part (left side) shows a complex and dark diffraction contrast compared to the very uniform appearance of the unaltered part (right side). d, e, f Electron diffraction patterns taken from the altered part, the interface region and the unaltered part, respectively (zone axis: [001])

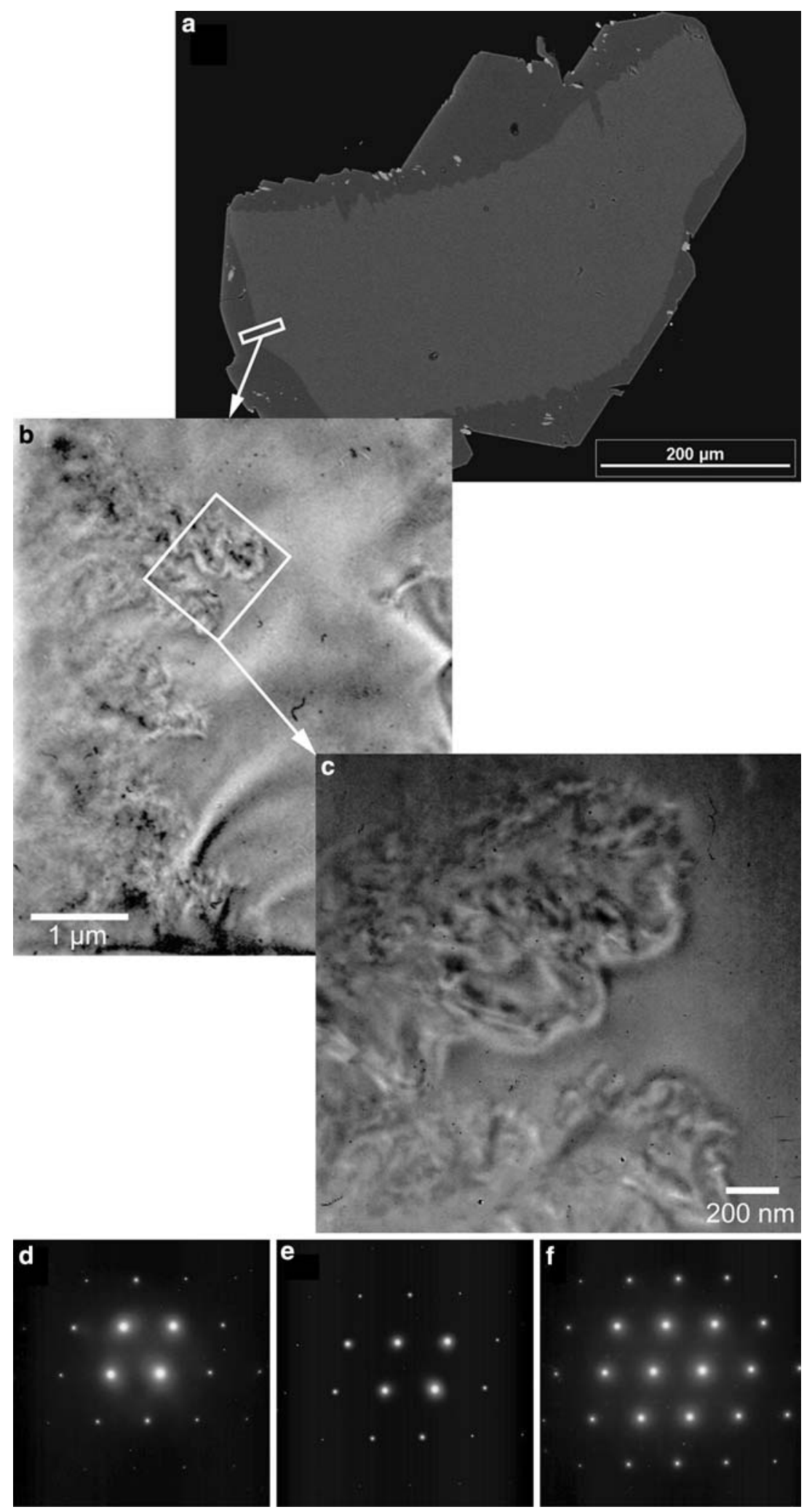

replaced by ${ }^{18} \mathrm{O}$. In such case we would expect a frequency shift of about -19.6 and $-18.4 \mathrm{~cm}^{-1}$ for the band near 509 and $479 \mathrm{~cm}^{-1}$, respectively. Assuming a linear correlation, we obtain ${ }^{18} \mathrm{O}$-concentrations of about $66 \%$ (band near
$509 \mathrm{~cm}^{-1}$ ) and $54 \%$ (band near $479 \mathrm{~cm}^{-1}$ ) from the measured frequency shift. The difference of these values indicates that the frequency shift due to the incorporation of ${ }^{18} \mathrm{O}$ is not equal for both modes. However, the value of 


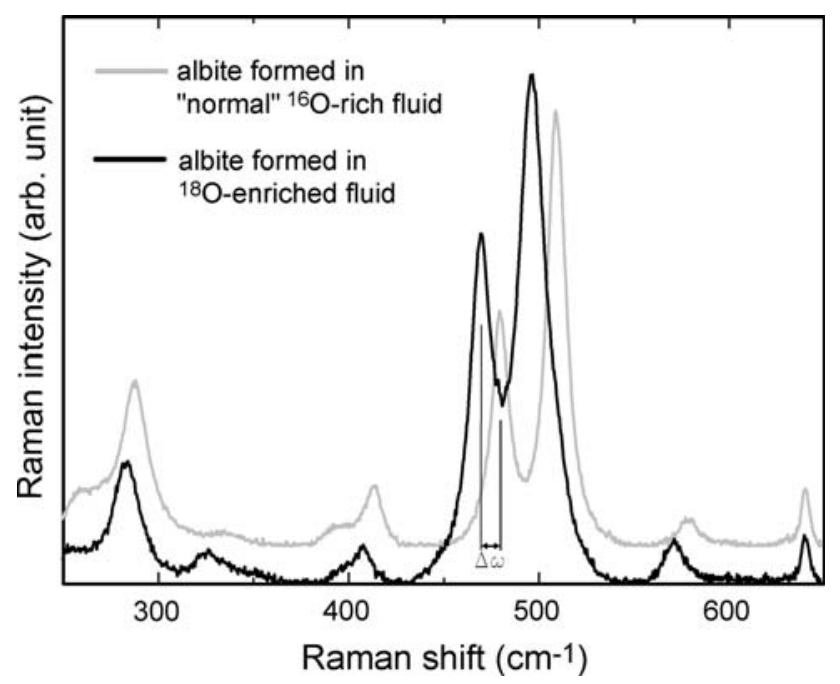

Fig. 6 Comparison of representative Raman spectra obtained from albite formed in "normal" (grey) and in ${ }^{18} \mathrm{O}$-enriched (black) sodium silicate solution. The most prominent Raman modes of albite near 509 and $479 \mathrm{~cm}^{-1}$ are shifted towards lower wavenumbers near 496 and $468 \mathrm{~cm}^{-1}$ in the black spectrum indicating that a significant amount of ${ }^{18} \mathrm{O}$ was incorporated in the tetrahedral framework

$66 \%$ must be an overestimate since the ${ }^{18} \mathrm{O}$-concentration of the fluid could not have exceeded the initial value of $62 \%$ during the reaction and a mass related isotope fractionation of the order of several percent can be ruled out.

In addition to single spot measurements, we collected spectra for a Raman mapping from an albite formed in the ${ }^{18} \mathrm{O}$-enriched solution. Figure 7 a shows a contour map of $\Delta \omega$, which is the difference between the measured value

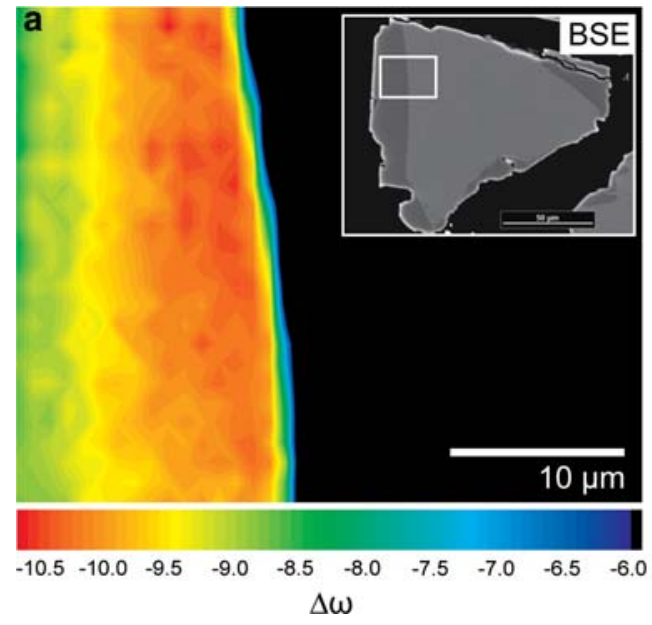

Fig. 7 a Raman contour map from an albite formed in ${ }^{18} \mathrm{O}$-enriched solution. Depicted is $\Delta \omega$, which is the difference between the measured value for the frequency of the bending mode near $468 \mathrm{~cm}^{-1}$ and the average frequency of this mode in ${ }^{16} \mathrm{O}$-rich albite $\left(=478.5 \mathrm{~cm}^{-1}\right)$. The mapped area is $28 \times 36 \mu \mathrm{m}$ large and outlined by a white rectangle in the BSE image. $\mathbf{b}$ Raman contour map from an albite formed in ${ }^{16} \mathrm{O}$-rich solution depicting the measured values for the frequency of the bending mode near $479 \mathrm{~cm}^{-1}$. The mapped area for the frequency of the bending mode near $468 \mathrm{~cm}^{-1}$ and the average frequency of this mode in ${ }^{16} \mathrm{O}$-rich albite $\left(=478.5 \mathrm{~cm}^{-1}\right)$. It is evident that the highest $\Delta \omega$ of around $-10.5 \mathrm{~cm}^{-1}$ only occurs close to the replacement interface. Near the free crystal surface the values are in the range of $-8.5 \mathrm{~cm}^{-1}$ giving an excess shift of about $-2 \mathrm{~cm}^{-1}$ at the replacement interface. To test whether this excess shift at the interface is due to local strain or chemical effects, we have produced another Raman map from albite formed in the "normal" ${ }^{16}$ O-rich solution. A comparable interfacial excess frequency shift was not detected in this map (Fig. 7b). The measured values show only slight variations between 478.4 and $478.8 \mathrm{~cm}^{-1}$, but these are not spatially related to the albite-oligoclase interface.

\section{Discussion}

The reaction mechanism

The textural and chemical features of the reaction products and the observed coupling between cation and oxygen isotope exchange are consistent with the results of similar experiments on the replacement of albite by K-feldspar, performed by Labotka et al. (2004) and by Niedermeier et al. (2009). All observations indicate that the replacement of plagioclase by albite, i.e. the coupled exchange of $\mathrm{Ca}^{2+}+\mathrm{Al}^{3+}$ by $\mathrm{Na}^{+}+\mathrm{Si}^{4+}$, proceeds via an interfacecoupled dissolution-reprecipitation mechanism. The chemical interface between the pristine plagioclase and the

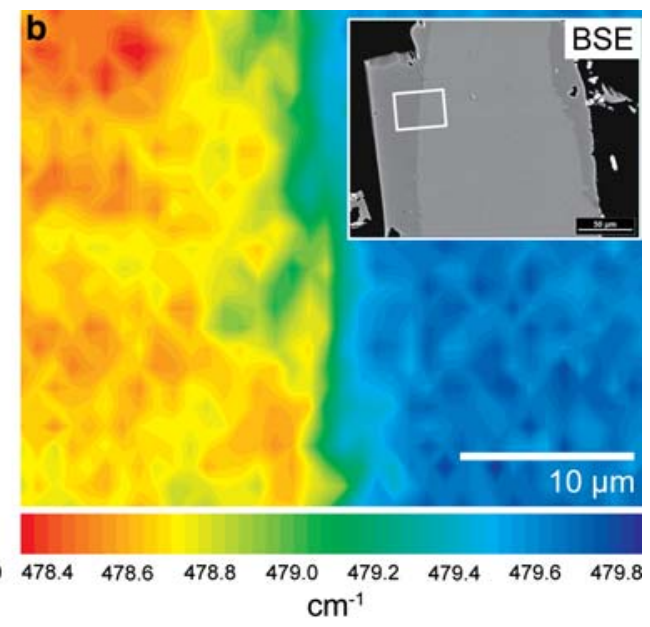

$(28 \times 36 \mu \mathrm{m})$ is again marked by a white rectangle in the BSE image. Both maps were measured row by row from the left to the right using a step size of $1 \mu \mathrm{m}$ in $x$ - and $y$-direction. Note: green to blue colours immediately at the interfaces are due to overlapping Raman signals from albite and oligoclase by reason of limited spatial and axial resolution of the laser spot. In $\mathbf{b}$ this overlap region is larger indicating a more inclined interface 
product albite is sharp on the micrometer scale as observed in BSE images, in EMP profiles, and in elemental distribution maps (Figs. 2, 3). A solid-state diffusion process is not able to produce such a sharp chemical change along the replacement interface. Furthermore, Raman spectroscopy clearly shows that the oxygen isotopes in the framework structure were redistributed during re-equilibration in the ${ }^{18} \mathrm{O}$-enriched fluid. Our estimation of the ${ }^{18} \mathrm{O}$-content indicates that the product albite almost completely inherited the oxygen isotope composition of the fluid. This is evidence that structural $\mathrm{Si}-\mathrm{O}$ and $\mathrm{Al}-\mathrm{O}$ bonds have been broken during the replacement and that the albite precipitated from the fluid. Again, a solid-state diffusion process is highly unlikely to cause such high isotope exchange rates (e.g. O'Neil and Taylor 1967; Cole and Chakraborty 2001; Fiebig and Hoefs 2002; Cole et al. 2004; Labotka et al. 2004; Bowman et al. 2009).

The observed excess Raman shift of about $-2 \mathrm{~cm}^{-1}$ near the replacement interface (Fig. 7a) can be either related to a higher ${ }^{18} \mathrm{O}$-content or to local tensile stress. It is likely that different thermal expansion coefficients and lattice mismatch between the plagioclase and the albite produce residual stress and strain fields at the interface. A strong tensile character of the stress may cause significant frequency decreases of lattice vibrations resulting in redshifts of the relevant Raman modes. However, if local stress is responsible for the excess Raman shift then comparable interfacial red-shifts should also be detectable for the Raman bands of ${ }^{16} \mathrm{O}$-rich albite. However, this could not be observed in our Raman mapping (Fig. 7b). Thus, the excess shift of $-2 \mathrm{~cm}^{-1}$ at the replacement interface must be related to a higher ${ }^{18} \mathrm{O}$-concentration. A rough estimate according to the calculation made above indicates that the ${ }^{18} \mathrm{O}$-content near the crystal surface is about $10 \%$ lower compared to the interface region. Previous studies have also observed a higher ${ }^{18} \mathrm{O}$-concentration close to the reaction interface (Geisler et al. 2005; Niedermeier et al. 2009). The reason for the ${ }^{18} \mathrm{O}$-enrichment at the interface is not yet understood. Niedermeier et al. (2009) performed similar experiments on the replacement of albite by $\mathrm{K}$-feldspar and found that ${ }^{18} \mathrm{O}$-enrichment at the replacement interface is correlated with enrichment of $\mathrm{K}$. In our experiments, however, there is no evidence for a chemically enriched interface. It might be possible that the ${ }^{18} \mathrm{O}$-enrichment is related to decreasing rates of dissolution and reprecipitation. Isotopic equilibration between the interfacial and the external fluid may remain incomplete since the reaction is faster in the initial stages. Thus, the ${ }^{16} \mathrm{O}$ coming from the dissolving plagioclase may be enriched in the interfacial fluid from which the albite precipitates. Slower dissolution and reprecipitation might later facilitate more complete isotopic equilibration between the interfacial and the external fluid. Nevertheless, at this point attempts to explain the ${ }^{18} \mathrm{O}$-enrichment near the replacement interface are highly speculative. A new experimental approach is required in order to develop an understanding of this phenomenon. Experimental systems providing fast replacement rates, as for example the calcite-hydroxylapatite system (Kasioptas et al. 2008), are likely to be most applicable for this purpose.

Although we have no direct observations of the replacement process, it is evident from BSE images (e.g. Fig. 2) that the external dimensions of the crystals were preserved during the reaction and that the reaction front moved from the surface or along pre-existing cracks inwards towards the centre. Such a mechanism for pseudomorphism requires (a) coupled rates of dissolution and reprecipitation at the reaction interface and (b) pathways through the reaction product providing fluid access to the replacement front (Putnis 2002; Putnis and Putnis 2007). Therefore, interconnected porosity must be generated during this process. The development of large pores is obvious in surface images of reacted plagioclase grains (Fig. 1). In many cases these are filled with pectolite. The molar volume decrease from plagioclase to albite is just about $1 \%$ and can therefore only play a minor role in the generation of porosity. Thus, the porosity must predominantly stem from the solubility difference between the two feldspars in the fluid. Since albite is more stable (or less soluble) than plagioclase in the presence of the aqueous sodium silicate solution, it follows that the amount of dissolving plagioclase exceeds the amount of reprecipitating albite.

The observation that pectolite is often located in notches at the crystal surface (Fig. 2) suggests that some of the surface porosity is related to the growth of pectolite. Proceeding albitisation increases the Ca-concentration in the fluid until it becomes supersaturated with respect to pectolite. Pectolite may then start to nucleate onto the surface of the partly replaced crystal. This may locally decrease the degree of saturation with respect to albite, similar to a flushing of the system (Berner 1978), so that subsequently some albite would dissolve, resulting in a notch at the surface.

Besides the obvious porosity at the surface, however, there is a lack of visible micro-porosity inside the albite replacement rim (Fig. 2). The unusual diffraction contrast which implies considerable strain, as well as the observation that the albitised parts are much more sensitive to the electron beam than the unreacted material, may indicate a higher porosity that is most probably present on the submicron scale. Once the reactivity of the fluid has decreased, it is also possible that some porosity was eliminated by textural re-equilibration and recrystallisation of pore space due to ripening processes, as has been observed experimentally in other replacement processes (Putnis et al. 
2005). Ripening processes together with pectolite precipitation, closing surface porosity, block a significant part of the available fluid pathways and slow down the forward propagation of the reaction interface. Experiments by Harlov et al. (2005) revealed that solid-state diffusion can become the predominant process at the interface as a result of this effect and consequently blurs the sharpness of the chemical interface. Our observation that the average replacement rim widths after 14 and 21 days are not noticeably different provides evidence that the process of dissolution and reprecipitation is indeed slowed down. However, since the interface is sharp on the nano-scale, as observed by TEM, solid-state diffusion is still subordinate to dissolution and reprecipitation within the duration of our experiments.

The observation that the albite reaction rim width varies from grain to grain and within single grains can have various causes. It is known that $\mathrm{Al}-\mathrm{O}$ bonds are energetically easier to break than $\mathrm{Si}-\mathrm{O}$ bonds (e.g. Xiao and Lasaga 1994). Therefore, it seems to be likely that the reaction kinetics is influenced by the crystallographic direction when considering the atomic sites present on different crystal surfaces. For instance, Arvidson et al. (2004) found that dissolution rates developed on the (010) cleavage face of albite are faster than those on the (001) cleavage face. They suggest that this may be a consequence of an anisotropic distribution of $\mathrm{Al}-\mathrm{O}-\mathrm{Si}$ and $\mathrm{Si}-\mathrm{O}-\mathrm{Si}$ bonds in the feldspar structure. However, it is also possible that the access of fluid to the mineral surface is locally variable within the gold capsule since the experiments were performed in static runs. Since the feldspar dissolution rate has been shown to depend on the fluid-to-solid ratio (Huang et al. 1986), the consequence would be a variable reaction rim width. In some cases, for example in those grains chosen for Raman mapping (Fig. 7), it is evident that parts of the albite rim were broken off from the crystal due to the preparation procedure.

Currently, the origin and exact composition of the complex intergrowth zones in partly replaced labradorites (Fig. 2d, e) are not entirely clear. It is obvious that these zones are not present throughout the whole crystal but whenever they occur they are located between the pristine labradorite and the pure product albite. Therefore, it appears that at first the replacement of labradorite by albite proceeds as in oligoclase and then at certain points these intergrowth zones start to form. A possible explanation could be that they form when the chemical exchange between the external and the interfacial fluid becomes inhibited due to the increasing rim thickness, driving the interfacial fluid increasingly away from equilibrium with the outer fluid reservoir. Since the release of $\mathrm{Ca}$ from a dissolving labradorite is greater compared to the Ca-release from a dissolving oligoclase, the interfacial fluid may have locally become supersaturated with respect to pectolite which then precipitates at the interface and within the pores. For the same reason described above this again would possibly result in dissolution of some albite explaining the coarse porosity within the intergrowth zones. A similar scenario was also proposed for the metastable formation of aeschynite during hydrothermal alteration of titanite-based pyrochlore (Pöml et al. 2007) and of $\mathrm{CeO}_{2}$ during the replacement of Y-stabilized zirconia-ceria ceramics (Plümper et al., in prep.). The metastable formation of monazite during the experimental replacement of fluorapatite by hydroxyapatite (Harlov et al. 2005) may be related to the same phenomenon.

The electron diffraction patterns obtained from the TEM investigations demonstrate that the crystallographic orientation of the parent plagioclase is almost perfectly preserved during albitisation. This is also a common feature of an interface-coupled dissolution-reprecipitation mechanism since the product phase nucleates epitaxially on the surface of the dissolving parent phase (Putnis and Putnis 2007). The product albite shows a complex diffraction contrast in bright-field TEM images (Fig. 5), which appears to be very similar to the diffraction contrast of naturally albitised plagioclase reported by Engvik et al. (2008). These authors attribute this contrast to a high density of dislocations and point defects and to elastic strain due to the volume decrease and the lattice misfit between the plagioclase and the albite at the replacement interface. As mentioned above, it is also reasonable that different thermal expansion coefficients between the two feldspars can cause strain at the interface when the crystals are cooled down to room temperature after experimental treatment.

Plagioclase albitisation and element mobility

Many studies on natural samples raise the question regarding which reaction best represents albitisation of plagioclase (e.g. Morad et al. 1990; Perez and Boles 2005; Engvik et al. 2008). A subject of much debate is the mobility of Al. For instance, the albitisation of oligoclase in our experiments can be expressed by two reactions which are fundamentally different regarding Al-mobility:

$$
\begin{aligned}
& \mathrm{Ca}_{0.22} \mathrm{Na}_{0.74} \mathrm{~K}_{0.04} \mathrm{Al}_{1.22} \mathrm{Si}_{2.78} \mathrm{O}_{8}+0.59 \mathrm{Na}^{+}(\mathrm{aq})+0.59 \mathrm{OH}^{-} \\
& +0.55 \mathrm{SiO}_{2}+0.22 \mathrm{H}_{2} \mathrm{O} \\
& \Rightarrow(1-x) \mathrm{NaAlSi}_{3} \mathrm{O}_{8}+x \mathrm{NaAlSi}_{3} \mathrm{O}_{8}(\mathrm{aq}) \\
& \text { albite(prec.) albite(sol.) } \\
& +\underset{\text { pectolite }}{0.11 \mathrm{NaCa}_{2} \mathrm{Si}_{3} \mathrm{O}_{8} \mathrm{OH}} \\
& +0.22 \mathrm{NaAl}(\mathrm{OH})_{4}^{0}+0.04 \mathrm{~K}^{+}(\mathrm{aq})+0.04 \mathrm{OH}^{-}
\end{aligned}
$$




$$
\begin{aligned}
& \mathrm{Ca}_{0.22} \mathrm{Na}_{0.74} \mathrm{~K}_{0.04} \mathrm{Al}_{1.22} \mathrm{Si}_{2.78} \mathrm{O}_{8}+0.59 \mathrm{Na}^{+}(\mathrm{aq}) \\
& +\underset{\mathrm{ol}^{2}}{0.59 \mathrm{OH}^{-}}+1.21 \mathrm{SiO}_{2} \\
& \Rightarrow \underset{\text { albite }}{1.22 \mathrm{NaAlSi}_{3} \mathrm{O}_{8}}+0.11 \mathrm{NaCa}_{2} \mathrm{Si}_{3} \mathrm{O}_{8} \mathrm{OH}+0.04 \mathrm{~K}^{+}(\mathrm{aq}) \\
& \quad+0.04 \mathrm{OH}^{-}+0.22 \mathrm{H}_{2} \mathrm{O}
\end{aligned}
$$

However, on the basis of our results only reaction (1) can be considered. Immobility of $\mathrm{Al}$ (reaction 2) would imply that $1 \mathrm{~mol}$ of oligoclase is replaced by $1.22 \mathrm{~mol}$ of albite. We would then expect the formation of albite overgrowth to occur. However, the textural characteristics of the reaction products indicate that the replacement is pseudomorphic, i.e. the volume is preserved. We have already argued that the difference between the solubilities of albite and plagioclase in the fluid mainly accounts for the porosity. This implies that the amount of albite precipitated from the fluid is lower than the amount of dissolved oligoclase. In reaction (1), this difference is regarded by a stoichiometric factor $x$ describing the amount of albite staying in solution. As a consequence $\mathrm{Al}_{2} \mathrm{O}_{3}$ has to be liberated along with $\mathrm{CaO}$ during the reaction as is demonstrated in the isocon diagrams (Figs. 4a, c).

The striking evidence that $\mathrm{Al}$ is released by the reaction is the fact that the amorphous silica-rich phase-formed from the residual fluid during the drying procedure of the reacted sample material-contains high concentrations of $\mathrm{Al}\left(\sim 10 \mathrm{wt} \% \mathrm{Al}_{2} \mathrm{O}_{3}\right)$, which is in contrast to the $\mathrm{Al}$-free blank amorphous phase prepared from the starting solution (Table 3). The absence of any secondary Al-bearing mineral phase except for albite demonstrates high solubility and therefore high mobility of $\mathrm{Al}$ in the experimental fluid.

Diakonov et al. (1996) demonstrated that the Al-solubility in a crustal fluid is mainly controlled by the formation of $\mathrm{Na}-\mathrm{Al}$ complexes such as $\mathrm{NaAl}(\mathrm{OH})_{4}^{0}$. The association constant of these complexes and thus the solubility of $\mathrm{Al}_{2} \mathrm{O}_{3}$ increases with increasing temperature and $\mathrm{Na}^{+}$-concentration in the fluid. Anderson and Burnham (1983) argued that other ligands such as $\mathrm{Cl}^{-}$may effectively compete with $\mathrm{Al}^{3+}$ for the available $\mathrm{Na}^{+}$. Therefore, the $\mathrm{Cl}^{-}$-concentration in a hydrothermal fluid may be a limiting factor for Almobility. The high Al-solubility observed in this study may thus be explained by the fact that the concentration of competing ligands in the initial fluid is very low.

Hence, our results demonstrate that Al can be remarkably mobile under hydrothermal conditions similar to our experiments, i.e. when a hot and alkaline fluid is involved. Al-mobility during metasomatism has already been documented by Nijland and Touret (2001). Nevertheless, in most situations Al is considered to be immobile (e.g. Mark 1998; Sandström et al. 2008). Either knowledge of the fluid composition or cogent textural evidence is required in order to justify the assumption of Al-immobility.
Minor and trace element analyses of the altered and unaltered plagioclases record considerable losses of $\mathrm{Ti}, \mathrm{Fe}$, $\mathrm{Mg}, \mathrm{Sr}, \mathrm{Ba}, \mathrm{Y}, \mathrm{K}, \mathrm{Rb}, \mathrm{Pb}$ and the LREEs (Fig. 4). LA-ICPMS and EMP analyses of the amorphous phases indicate that these elements were introduced to the solution during albitisation of both oligoclase and labradorite (Tables 3,4). As the trace element composition of pectolite is unknown it cannot be excluded that some of these elements were subsequently incorporated in pectolite. However, it is obvious that the concentrations of $\mathrm{Ti}, \mathrm{Fe}, \mathrm{Mg}, \mathrm{Sr}, \mathrm{Ba}, \mathrm{Rb}$, $\mathrm{Pb}, \mathrm{La}, \mathrm{Ce}$ and $\mathrm{Eu}$ are remarkably higher in the amorphous phases after experimental treatment. This strongly suggests that these elements go into solution.

$\mathrm{Sr}, \mathrm{Eu}$ and to a lesser extent Ba can substitute for Ca. Therefore, it seems reasonable that they are liberated along with $\mathrm{Ca}$ upon albitisation. The observation that the amorphous phases are strongly enriched in $\mathrm{Sr}, \mathrm{Ba}$ and $\mathrm{Eu}$ after experimental treatment, however, indicates that they stay in solution rather than being incorporated into the pectolite.

$\mathrm{Ti}$ and the REEs are also often regarded as immobile during hydrothermal processes due to their low solubility in aqueous fluids under most geologic conditions. REEmobility during albitisation, however, has been reported from several studies (e.g. Baker 1985; Munz et al. 1994). Furthermore, some authors have argued that $\mathrm{Ti}$ and other high field strength elements (HFSE) such as $\mathrm{Zr}$, Hf or Ta are fairly mobile under certain hydrothermal conditions and therefore advise against interpretation of altered rocks on the basis of their trace element composition (e.g. Gierè 1990; Jiang et al. 2005). In our experiments it is clear that $\mathrm{Ti}$ and LREEs such as $\mathrm{La}, \mathrm{Ce}$ and Eu are mobilised. Regarding the REEs it may be suggested that complexation with $\mathrm{OH}^{-}$is responsible for their mobilisation (Haas et al. 1995). $\mathrm{Ti}^{4+}$ may be mobilised by complexing solely with $\mathrm{OH}^{-}$(van Baalen 1993) or by associating with $\mathrm{Na}^{+}$and $\mathrm{OH}^{-}$and thus competing with $\mathrm{Al}^{3+}$ for $\mathrm{Na}^{+}$(Manning et al. 2008).

\section{Conclusions}

Our experimental results strongly indicate that albitisation of plagioclase proceeds via an interface-coupled dissolution-reprecipitation mechanism. This mechanism allows for pervasive fluid infiltration due to the simultaneous generation of porosity in the albite product which can greatly enhance the fluid flow through the rock. Furthermore, albitising fluids that are hot and alkaline have a high capability for mobilisation and transport of a wide variety of trace elements since complexation with $\mathrm{OH}^{-}$and $\mathrm{Na}^{+}$ can effectively increase the solubility of elements, even those that are often regarded as immobile (e.g. Al, Ti or the REEs). As an albitising fluid migrates through a rock away 
from its source the activity of complexing ligands within this fluid will decrease upon cooling or changes in composition due to fluid mixing or wall-rock reactions. Thus, the solubilities of transported elements decrease resulting in deposition of these elements.

To obtain results within an appropriate experimental time a fluid with high $\mathrm{NaOH}$ and $\mathrm{SiO}_{2}$ concentrations was used. These may be barely realised in nature, but-on geological time scales-a much less concentrated fluid may be sufficient to replace crustal rock units on a regional scale by an albite-rich mineralogy and to remobilise considerable amounts of elements.

Our experiments were performed in a closed system disregarding the possibility that a continuous fluid flow in nature would yield permanent renewal of the albitising fluid. However, this may have a great effect on dissolution of plagioclase and precipitation of albite. Hence, experiments in a flow-through reactor may provide a sound approach for further investigations into the albitisation process.

Acknowledgments We thank Jasper Berndt-Gerdes for assistance at the electron microprobe and the LA-ICP-MS and Martina Menneken for help with single Raman measurements. We are also grateful to Paul Löbke who prepared the polished sample sections. We appreciate the comments and suggestions of two anonymous reviewers, which helped to improve the manuscript. We thank Carl Francis of the Mineralogical Museum, Harvard University for the labradorite samples and the DFG (Deutsche Forschungsgemeinschaft - German Research Foundation) for financial support for the experimental laboratories. Part of this work was also supported by the EU Research Training Network, MIN-GRO.

\section{References}

Anderson GM, Burnham CW (1983) Feldspar solubility and the transport of aluminium under metamorphic conditions. Am J Sci 283:283-297

Arvidson RS, Beig MS, Luttge A (2004) Single-crystal plagioclase feldspar dissolution rates measured by vertical scanning interferometry. Am Mineral 89(1):51-56

Baccar MB, Fritz B, Made B (1993) Diagenetic albitization of Kfeldspar and plagioclase in sandstone reservoirs-thermodynamic and kinetic modeling. J Sediment Petrol 63(6):1100-1109. doi:10.1306/D4267CB2-2B26-11D7-8648000102C1865D

Baker JH (1985) Rare-earth and other trace-element mobility accompanying albitization in a Proterozoic granite, W. Bergslagen, Sweden. Mineral Mag 49(350):107-115

Berner RA (1978) Rate control of mineral dissolution under earth surface conditions. Am J Sci 278(9):1235-1252

Bjørlykke A, Cumming GL, Krstic D (1990) New isotopic data from davidites and sulfides in the Bidjovagge gold-copper deposit, Finnmark, northern Norway. Mineral Petrol 43(1):1-21. doi: 10.1007/BF01164218

Boles JR (1982) Active albitization of plagioclase, Gulf-Coast Tertiary. Am J Sci 282(2):165-180

Bowman JR, Valley JW, Kita NT (2009) Mechanisms of oxygen isotopic exchange and isotopic evolution of ${ }^{18} \mathrm{O} /{ }^{16} \mathrm{O}$-depleted periclase zone marbles in the Alta aureole, Utha: insights from ion microprobe analysis of calcite. Contrib Mineral Petrol 157:77-93. doi:10.1007/s00410-008-0321-1

Clark C, Mumm AS, Faure K (2005) Timing and nature of fluid flow and alteration during Mesoproterozoic shear zone formation, Olary Domain, South Australia. J Metamorph Geol 23(3):147164. doi:10.1111/j.1525-1314.2005.00568.x

Cole DR, Chakraborty S (2001) Rates and mechanisms of isotopic exchange. Rev Mineral Geochem 43:83-223. doi:10.2138/ gsrmg.43.1.83

Cole DR, Larson PB, Riciputi LR, Mora CI (2004) Oxygen isotope zoning profiles in hydrothermally altered feldspars: estimating the duration of water-rock interaction. Geology 32:29-32. doi: 10.1130/G19881.1

Deer WA, Howie RA, Zussman J (1992) An introduction to the rock forming minerals. Pearson Education Limited, Harlow

Diakonov I, Pokrovski G, Schott J, Castet S, Gout R (1996) An experimental and computational study of sodium-aluminum complexing in crustal fluids. Geochim Cosmochim Acta 60(2):197-211. doi:10.1016/0016-7037(95)00403-3

Engvik AK, Putnis A, Fitz Gerald JD, Austrheim H (2008) Albitisation of granitic rocks: the mechanism of replacement of oligoclase by albite. Can Mineral 46(6):1401-1415. doi: 10.3749/canmin.46.6.1401

Fiebig J, Hoefs J (2002) Hydrothermal alteration of biotite and plagioclase as inferred from intragranular oxygen isotope- and cation-distribution patterns. Eur J Mineral 14:49-60. doi: 10.1127/0935-1221/2002/0014-0049

Frietsch R, Tuisku P, Martinsson O, Perdahl JA (1997) Early Proterozoic $\mathrm{Cu}-\mathrm{Au})$ and $\mathrm{Fe}$ ore deposits associated with regional $\mathrm{Na}-\mathrm{Cl}$ metasomatism in northern Fennoscandia. Ore Geol Rev 12(1):1-34. doi:10.1016/S0169-1368(96)00013-3

Geisler T, Pöml P, Stephan T, Janssen A, Putnis A (2005) Experimental observation of an interface-controlled pseudomorphic replacement reaction in a natural crystalline pyrochlore. Am Mineral 90(10):1683-1687. doi:10.2138/am.2005.1970

Gierè R (1990) Hydrothermal mobility of Ti, $\mathrm{Zr}$ and REE: examples from the Bergell and Adamello contact aureoles (Italy). Terra Nova 2:60-67. doi:10.1111/j.1365-3121.1990.tb00037.x

Grant JA (1986) The isocon diagram - a simple solution to Gresens' equation for metasomatic alteration. Econ Geol 81(8):19761982

Gresens RL (1967) Composition-volume relationships of metasomatism. Chem Geol 2:47-65. doi:10.1016/0009-2541(67)90004-6

Haas JR, Shock EL, Sassani DC (1995) Rare-earth elements in hydrothermal systems - estimates of standard partial molal thermodynamic properties of aqueous complexes of the rareearth elements at high pressures and temperatures. Geochim Cosmochim Acta 59(21):4329-4350. doi:10.1016/0016-7037 (95)00314-P

Harlov DE, Wirth R, Forster HJ (2005) An experimental study of dissolution-reprecipitation in fluorapatite: fluid infiltration and the formation of monazite. Contrib Mineral Petrol 150(3):268286. doi:10.1007/s00410-005-0017-8

Hellmann R (1994) The albite-water system: Part I. The kinetics of dissolution as a function of $\mathrm{pH}$ at 100,200 , and $300^{\circ} \mathrm{C}$. Geochim Cosmochim Acta 58(2):595-611. doi:10.1016/0016-7037(94) 90491-X

Hellmann R, Penisson JM, Hervig RL, Thomassin JH, Abrioux MF (2003) An EFTEM/HRTEM high-resolution study of the near surface of labradorite feldspar altered at acid $\mathrm{pH}$ : evidence for interfacial dissolution-reprecipitation. Phys Chem Minerals 30:192-197. doi:10.1007/s00269-003-0308-4

Huang WL, Bishop AM, Brown RW (1986) The effect of fluid/rock ratio on feldspar dissolution and illite formation under reservoir conditions. Clay Miner 21(4):585-601. doi:10.1180/claymin. 1986.021.4.10 
Jiang SY, Wang RC, Xu XS, Zhao KD (2005) Mobility of high field strength elements (HFSE) in magmatic-, metamorphic-, and submarine-hydrothermal systems. Phys Chem Earth 30:1020 1029. doi:10.1016/j.pce.2004.11.004

Kasioptas A, Perdikouri C, Putnis CV, Putnis A (2008) Pseudomorphic replacement of single calcium carbonate crystals by polycrystalline apatite. Mineral Mag 72(1):77-80. doi:10.1180/ minmag.2008.072.1.77

Kent AJR, Ashley PM, Fanning CM (2000) Metasomatic alteration associated with regional metamorphism: an example from the Willyama Supergroup, South Australia. Lithos 54(1-2):33-62. doi:10.1016/S0024-4937(00)00021-9

Kieffer SW (1982) Thermodynamics and lattice-vibrations of minerals: 5. Applications to phase-equilibria, isotopic fractionation, and high-pressure thermodynamic properties. Rev Geophys 20(4):827-849. doi:10.1029/RG020i004p00827

Labotka TC, Cole DR, Fayek M, Riciputi LR, Stadermann FJ (2004) Coupled cation and oxygen-isotope exchange between alkali feldspar and aqueous chloride solution. Am Mineral 89:1822-1825

Lee MR, Parsons I (1997) Dislocation formation and albitization in alkali feldspars from the Shap granite. Am Mineral 82(5-6):557570

Manning CE, Wilke M, Schmidt C, Cauzid J (2008) Rutile solubility in albite- $\mathrm{H}_{2} \mathrm{O}$ and $\mathrm{Na}_{2} \mathrm{Si}_{3} \mathrm{O}_{7}-\mathrm{H}_{2} \mathrm{O}$ at high temperatures and pressures by in situ synchrotron radiation micro-XRF. Earth Planet Sci Lett 272(3-4):730-737. doi:10.1016/j.eps1.2008. 06.004

Mark G (1998) Albitite formation by selective pervasive sodic alteration of tonalite plutons in the Cloncurry district, Queensland. Aust J Earth Sci 45(5):765-774. doi:10.1080/08120099 808728431

McKeown DA (2005) Raman spectroscopy and vibrational analyses of albite: from $25^{\circ} \mathrm{C}$ through the melting temperature. Am Mineral 90(10):1506-1517. doi:10.2138/am.2005.1726

Moody JB, Jenkins JE, Meyer D (1985) An experimental investigation of the albitization of plagioclase. Can Mineral 23:583-596

Morad S, Bergan M, Knarud R, Nystuen JP (1990) Albitization of detrital plagioclase in Triassic reservoir sandstones from the Snorre Field, Norwegian North Sea. J Sediment Petrol 60(3):411425. doi:10.1306/212F91AB-2B24-11D7-8648000102C1865D

Munz IA, Wayne D, Austrheim H (1994) Retrograde fluid infiltration in the high-grade Modum Complex, South Norway: evidence for age, source and REE mobility. Contrib Mineral Petrol 116(12):32-46. doi:10.1007/BF00310688

Niedermeier DRD, Putnis A, Geisler T, Golla-Schindler U, Putnis CV (2009) The mechanism of cation and oxygen isotope exchange in alkali feldspars under hydrothermal conditions. Contrib Mineral Petrol 157(1):65-76. doi:10.1007/s00410-008-0320-2

Niiranen T, Mänttäri I, Poutiainen M, Oliver NHS, Miller JA (2005) Genesis of Palaeoproterozoic iron skarns in the Misi region, northern Finland. Mineral Depos 40:192-217. doi:10.1007/ s00126-005-0481-0

Nijland TG, Touret JLR (2001) Replacement of graphic pegmatite by graphic albite-actinolite-clinopyroxene intergrowths (Mjåvatn, southern Norway). Eur J Mineral 13(1):41-50. doi:10.1127/ 0935-1221/01/0013-0041

O'Neil JR, Taylor HP (1967) The oxygen isotope and cation exchange chemistry of feldspars. Am Mineral 52:1414-1437
Oliver NHS, Cleverley JS, Mark G, Pollard PJ, Fu B, Marshall LJ, Rubenach MJ, Williams PJ, Baker T (2004) Modeling the role of sodic alteration in the genesis of iron oxide-copper-gold deposits, Eastern Mount Isa block, Australia. Econ Geol 99(6):1145-1176. doi:10.2113/99.6.1145

Orville PM (1972) Plagioclase cation-exchange equilibria with aqueous chloride solution: results at $700^{\circ} \mathrm{C}$ and 2000 bars in presence of quartz. Am J Sci 272(3):234-272

Perez R, Boles AR (2005) An empirically derived kinetic model for albitization of detrital plagioclase. Am J Sci 305(4):312-343

Petersson J, Eliasson T (1997) Mineral evolution and element mobility during episyenitization (dequartzification) and albitization in the postkinematic Bohus granite, southwest Sweden. Lithos 42(1-2):123-146. doi:10.1016/S0024-4937(97)00040-6

Plümper O, Putnis A (2009) The complex hydrothermal history of granitic rocks: multiple feldspar replacement reactions under subsolidus conditions. J Petrol. doi: 10.1093/petrology/egp028

Pöml P, Menneken M, Stephan T, Niedermeier DRD, Geisler T, Putnis A (2007) Mechanism of hydrothermal alteration of natural self-irradiated and synthetic crystalline titanate-based pyrochlore. Geochim Cosmochim Acta 71(13):3311-3322. doi: 10.1016/j.gca.2007.03.031

Putnis A (2002) Mineral replacement reactions: from macroscopic observations to microscopic mechanisms. Mineral Mag 66:689708. doi: $10.1180 / 0026461026650056$

Putnis A, Putnis CV (2007) The mechanism of reequilibration of solids in the presence of a fluid phase. J Solid State Chem 180(5):1783-1786. doi:10.1016/j.jssc.2007.03.023

Putnis CV, Tsukamoto K, Nishimura Y (2005) Direct observations of pseudomorphism: compositional and textural evolution at a fluid-solid interface. Am Mineral 90:1909-1912. doi:10.2138/ am.2005.1990

Putnis CV, Geisler T, Schmid-Beurmann P, Stephan T, Giampaolo C (2007) An experimental study of the replacement of leucite by analcime. Am Mineral 92(1):19-26. doi:10.2138/am.2007.2249

Sandström B, Annersten H, Tullborg EL (2008) Fracture-related hydrothermal alteration of metagranitic rock and associated changes in mineralogy, geochemistry and degree of oxidation: a case study at Forsmark, central Sweden. Int J Earth Sci (Geol Rundsch). doi: 10.1007/s00531-008-0369-1

Schliestedt M, Johannes W (1990) Cation exchange equilibria between plagioclase and aqueous chloride solution at 600 to $700^{\circ} \mathrm{C}$ and 2 to $5 \mathrm{kbar}$. Eur J Mineral 2(3):283-295

Schliestedt M, Matthews A (1987) Cation and oxygen isotope exchange between plagioclase and aqueous chloride solution. Neues Jahrb Min 6:241-248

Smith M, Coppard J, Herrington R, Stein H (2007) The geology of the Rakkurijärvi $\mathrm{Cu}-(\mathrm{Au})$ prospect, Norrbotten: a new iron oxidecopper-gold deposit in northern Sweden. Econ Geol 102(3):393414. doi:10.2113/gsecongeo.102.3.393

Van Baalen MR (1993) Titanium mobility in metamorphic systems: a review. Chem Geol 110(1-3):233-249

Xiao Y, Lasaga AC (1994) Ab initio quantum mechanical studies of the kinetics and mechanisms of silicate dissolution $\mathrm{H}^{+}\left(\mathrm{H}_{3} \mathrm{O}^{+}\right)$ catalysis. Geochim Cosmochim Acta 58:5379-5400. doi: 10.1016/0016-7037(94)90237-2 